\title{
Słuchowe potencjały korowe - kliniczne zastosowanie oraz ocena przydatności w diagnostyce ośrodkowych procesów słuchowych
}

\section{Cortical auditory evoked potentials - clinical applications and usability in central auditory processes evaluation}

\author{
Rafat Milner \\ Instytut Fizjologii i Patologii Słuchu, Światowe Centrum Słuchu, Zakład Audiologii Eksperymentalnej, \\ Warszawa/Kajetany
}

Adres autora: Rafał Milner, Światowe Centrum Słuchu, Zakład Audiologii Eksperymentalnej, ul. Mokra 17, Kajetany, 05-830 Nadarzyn, e-mail: r.milner@ifps.org.pl

\section{Streszczenie}

Słuchowe potencjały korowe (ang. cortical auditory evoked potentials, CAEP) to bioelektryczne odpowiedzi mózgu na bodźce dźwiękowe, generowane w ośrodkach nerwowych znajdujących się na wyższych piętrach analizy informacji słuchowej. Wiele dotychczas przeprowadzonych badań eksperymentalnych pokazuje, że rejestracja oraz ocena tych odpowiedzi stwarza olbrzymie możliwości w diagnostyce audiologicznej oraz innych dziedzinach nauki, w których konieczne bądź potrzebne jest sprawdzenie stanu funkcjonalnego ośrodków mózgowych i procesów związanych z przetwarzaniem bodźców dźwiękowych. Niniejsza praca zawiera przegląd najczęściej opisywanych w literaturze sensorycznych (egzogennych) oraz związanych ze zdarzeniem (endogennych) składowych słuchowych potencjałów korowych oraz przykłady klinicznego zastosowania tych komponentów w ocenie i diagnostyce ośrodkowych procesów słuchowych oraz związanych z nimi procesów poznawczych i językowych.

Słowa kluczowe: słuchowe potencjały korowe $\bullet$ klasyfikacja $\bullet$ schematy stymulacji • kliniczne zastosowanie • P1 • N1 • P2 • mismatch negativity $\bullet \mathrm{MMN} \bullet \mathrm{P} 3 \bullet \mathrm{N} 400$

\begin{abstract}
Cortical auditory evoked potentials (CAEP) are bioelectric brain responses evoked by acoustic stimuli and generated in different brain centres at higher levels of auditory processing. Many experimental studies conducted so far show that the registration and evaluation of these responses constitute great potential of opportunities in audiological diagnosis and other scientific fields where the verification of brain functional states and assessment of processes related to the acoustic stimuli analysis are needed. This paper provides an overview of the most commonly reported components of sensory evoked (egzogenous) and event-related (endogeneous) potentials. It presents numerous examples of their clinical application in the assessment and diagnosis of central auditory as well as cognitive and language processes.
\end{abstract}

Key words: cortical auditory evoked potentials • classification $\bullet$ experimental paradigms $\bullet$ clinical applications $\bullet$ P1 • N1 • $\mathrm{P} 2 \cdot$ mismatch negativity $\bullet \mathrm{MMN} \bullet \mathrm{P} 3 \cdot \mathrm{N} 400$

\section{Wprowadzenie}

Słuchowe potencjały korowe (ang. cortical auditory evoked potentials, CAEP) to bioelektryczne odpowiedzi mózgu na bodźce dźwiękowe, generowane w ośrodkach nerwowych znajdujących się na wyższych piętrach analizy informacji słuchowej, głównie w korze mózgu [1]. Słuchowe potencjały korowe, podobnie jak potencjały generowane przez bodźce innej modalności, dzieli się na dwie duże grupy: 1) sensoryczne potencjały wywołane (ang. sensory evoked potentials, $S E P$ ) oraz 2) potencjały związane ze zdarzeniem (ang. event-related potentials, ERP) [1].

Sensoryczne potencjały wywołane to odpowiedzi, które odzwierciedlają czuciową reakcję ośrodkowej części układu słuchowego. Za miejsce generacji składowych sensorycznych CAEP wskazuje się przede wszystkimi szlaki wzgórzowo-korowe oraz pierwszorzędową i asocjacyjną korę słuchową w płacie skroniowym [2]. Wielokrotnie udowodniono, że parametry składowych sensorycznych 
potencjałów wywołanych (amplituda, latencja) w dużym stopniu zależą od fizycznych parametrów bodźca wyzwalającego odpowiedź. Chociaż latencja, amplituda czy lokalizacja przestrzenna na powierzchni głowy tych komponentów mogą się różnić (zwłaszcza do 6 r.ż.), są one rejestrowane $\mathrm{z}$ dużą powtarzalnością zarówno u dorosłych, jak i u dzieci (również noworodków i niemowlaków). Cechą charakterystyczną składowych sensorycznych jest także niewielka zależność tych odpowiedzi od czynników związanych z osobą badaną, u której wykonuje się rejestracje. Komponenty sensoryczne określa się więc bardzo często mianem składowych egzogennych lub obligatoryjnych [1,2].

W przeciwieństwie do potencjałów sensorycznych, potencjały związane ze zdarzeniem nie są reprezentantem czuciowej odpowiedzi ośrodkowej części układu słuchowego, lecz stanowią bioelektryczny marker procesu neuronalnego związanego z pewnym specyficznym (ang. event) zdarzeniem. Zdarzenie to może mieć różną postać: zarówno pojawiającego się pojedynczego bodźca (którym może być na przykład ton prezentowany w specjalnie przygotowanej procedurze, odbierany jako odrębne zdarzenie), ale event może stanowić także pewien specyficzny ciąg bodźców (chociażby seria tonów o częstotliwości $1000 \mathrm{~Hz}$ zmieniających się w tony o częstotliwości $2000 \mathrm{~Hz}$ ). Wykazano również, że odpowiedź mózgowa ERP może pojawiać się nawet $\mathrm{w}$ reakcji na brak bodźca (np. w odpowiedzi na ominięcie jakiegoś tonu w sekwencji dźwięków). Zdarzeniem wywołującym odpowiedź może być także bodziec (ang. target), który posiada w danym momencie jakieś znaczenie. Wykazano, że cechą charakterystyczną wszystkich składowych związanych ze zdarzeniem jest duża zależność tych odpowiedzi od tzw. czynników „endogennych”. Są to różnego rodzaju zmienne zależne od osoby badanej, takie jak natężenie jej uwagi czy też poziom wykonania zadania, w którym pojawia się lub pojawiają się specyficzne bodźce związane z zadaniem. Składowe związane ze zdarzeniem bardzo często nazywa się więc składowymi endogennymi. Inną nazwą używaną zamiennie są komponenty czy też potencjały poznawcze. Sądzi się bowiem, że ERP są reprezentantem procesu(-ów) przetwarzania poznawczego bodźca zachodzącego(-ych) w strukturach czy obszarach mózgu niezaangażowanych wyłącznie w przetwarzanie bodźców akustycznych, lecz aktywnych po sensorycznym opracowaniu bodźca (zdarzenia) dźwiękowego [3].

\section{Sensoryczne (egzogenne) składowe słuchowych potencjałów korowych - charakterystyka, miejsce generacji, znaczenie funkcjonalne oraz schematy doświadczalne wykorzystywane najczęściej do generacji poszczególnych fal}

\section{Fala P1}

Pierwszą ze składowych sensorycznych (egzogennych) słuchowych potencjałów korowych stanowi fala określana jako P1 (rycina 1). Nazwa opisująca falę pochodzi od dodatniej polarności (ang. positive) charakteryzującej komponent i oznacza, iż jest to pierwsza ze składowych widoczna w odpowiedzi korowej. Fala P1 pojawia się w wyzwalanym potencjale korowym $\mathrm{z}$ latencją już w zakresie 55-80 ms po podaniu bodźca wywołującego odpowiedź. Tak wczesna latencja komponentu powoduje, że składową P1 bardzo często zalicza się do grupy wcześniejszych niż korowe
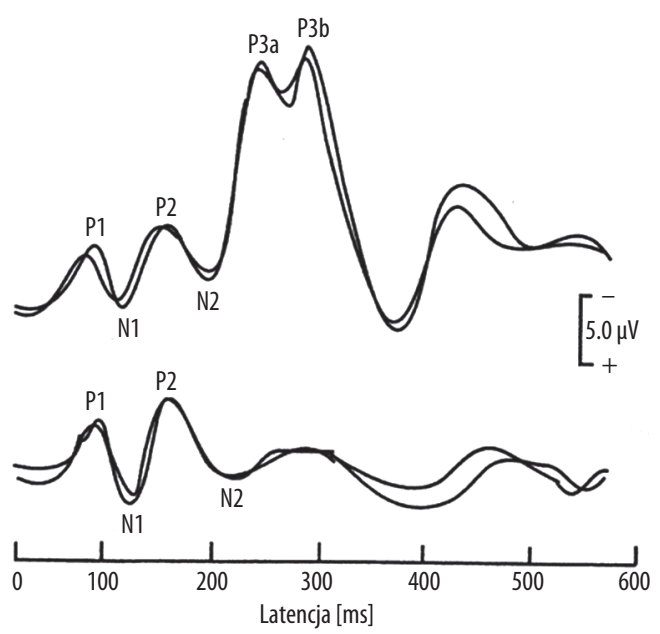

Rycina 1. Przykład słuchowych potencjałów korowych zarejestrowanych w odpowiedzi na bodźce słuchowe prezentowane w trakcie procedury „oddball”. Górna część ryciny przedstawia potencjał wywołany w odpowiedzi na bodźce „standard”. W odpowiedzi tej widać wyraźne składowe sensoryczne „egzogenne” (fale P1, N1, P2) oraz składową związaną ze zdarzeniem „endogenną” (falę N2) słuchowych potencjałów wywołanych. Dolna część ryciny przedstawia potencjał wywołany w odpowiedzi na rzadziej pojawiające się bodźce „dewiant”. W odpowiedzi tej oprócz składowych egzogennych (P1, N1, P2) i endogennej (N2) widać również wyraźnie zaznaczoną składową związaną ze zdarzeniem - falę P3 (widoczna w postaci dwóch załamków: P3a i P3b)

Figure 1. The example of cortical auditory evoked potentials recorded in responses to acoustic stimuli presented in active oddball paradigm. Upper part of the figure shows the potential evoked by standard stimuli. The sensory "exogenous" (P1, N1, P2 waves) and event-related "endogenous" component (N2 wave) are clearly visible in this response. Lower part of the figure shows the potential evoked by rarely appearing deviant stimuli. The P3 wave (occurs often in the form of two components: $\mathrm{P} 300 / \mathrm{P} 3 \mathrm{a}$ or $\mathrm{P} 300 \mathrm{~b} / \mathrm{P} 3 \mathrm{~b}$ ) is also included in brain responses in addition to the exogenous and endogenous components

potencjałów wywołanych tzw. potencjałów średniolatencyjnych. Jest ona określana wówczas mianem fali $\mathrm{Pb}$ [3].

Na przynależność komponentu P1 do wcześniejszych niekorowych odpowiedzi wywołanych wskazują również opisywane w literaturze generatory fali P1. Jako jeden $\mathrm{z}$ nich wymienia się zlokalizowane podkorowo drogi projekcyjne ze wzgórza do wejściowych pól pierwszorzędowej kory słuchowej [3]. Według innych badań źródłem fali P1 jest natomiast niespecyficzny polisensoryczny system projektujący do górnoskroniowej części kory słuchowej, która znajduje się po stronie przeciwległej do strony stymulacji [4].

Na temat funkcjonalnego znaczenia fali P1 można znaleźć w literaturze stosunkowo niewiele publikacji. Składowa P1 odzwierciedla więc prawdopodobnie aktywność w drogach nerwowych i części kory słuchowej opisywanych jako generator(-y) komponentu.

Schematem badawczym, którego zastosowanie umożliwia wygenerowanie fali P1, jest schemat określany z języka 


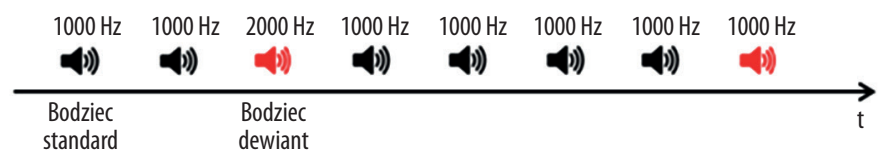

B

$1000 \mathrm{~Hz} 1000 \mathrm{~Hz} 2000 \mathrm{~Hz} 1000 \mathrm{~Hz} 1000 \mathrm{~Hz} 1000 \mathrm{~Hz} 2000 \mathrm{~Hz}$

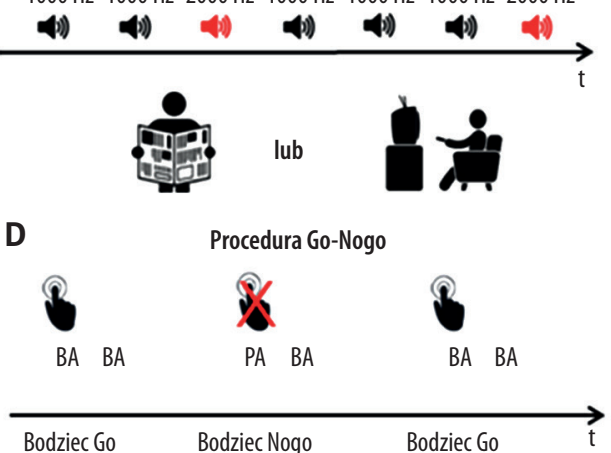

C

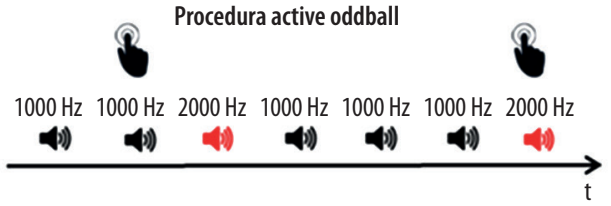

E
Procedura do rejestracji

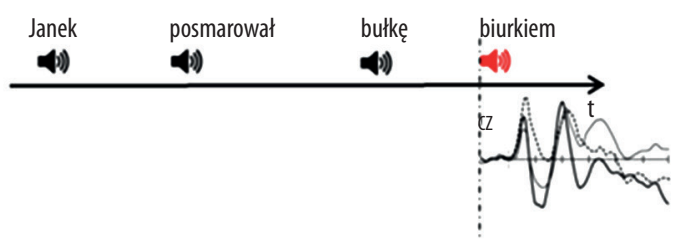

Rycina 2. Przykłady schematów doświadczalnych najczęściej wykorzystywanych podczas rejestracji słuchowych potencjałów korowych: (A) standardowej procedury „oddball” oraz jej wybranych wariantów - (B) pasywnej procedury „oddball” (ang. passive oddball paradigm) i (C) aktywnej procedury „oddball” (ang. active oddball paradigm). Na rycinie umieszczono również schemat paradygmatu Go-Nogo (D) oraz paradygmatu semantycznego (E)

Figure 2. The examples of different experimental paradigms used frequently in cortical auditory evoked potential recordings: (A) standard oddball paradigm and its different variants - (B) passive oddball paradigm and (C) active oddball paradigm. The schema of Go-Nogo paradigm (D) and semantic paradigm (E) are also included in the figure

angielskiego mianem paradygmatu czy też procedury „oddball” (rycina 2A). Został on po raz pierwszy opisany w 1975 roku i od tamtego czasu stanowi chyba jeden z najczęściej stosowanych paradygmatów w badaniach wykorzystujących potencjały korowe [5]. Schemat „oddball” w klasycznej słuchowej formie polega na prezentacji osobie biorącej udział w badaniu CAEP losowej sekwencji jednakowych, powtarzających się i często występujących tzw. bodźców „standard” (np. tonów $1000 \mathrm{~Hz}$ ) oraz wyróżniających się jakąś cechą i pojawiających się rzadziej bodźców "dewiant” (np. tonów o wyższej częstotliwości $2000 \mathrm{~Hz}$ ). Podczas prezentacji bodźców rejestrowany jest sygnał EEG, który po zakończeniu badania (ang. off-line) lub już nawet w jego trakcie (ang. on-line) jest odpowiednio przetwarzany $i$ analizowany. Jest on dzielony na fragmenty czasowo związane z każdym rodzajem bodźców, które są następnie nakładane na siebie i matematycznie uśredniane. $\mathrm{W}$ ten sposób $\mathrm{z}$ sygnału pochodzącego $\mathrm{z}$ wielu milionów komórek nerwowych w mózgu wyekstrahowana zostaje odpowiedź bioelektryczna generowana wyłącznie przez te neurony, których odpowiedź jest czasowo związana z poszczególnym rodzajem bodźca. Jako wynik badania otrzymywane są natomiast oddzielnie słuchowe potencjały korowe na bodźce „standard” i bodźce „dewiant” (szczegółowy opis technik rejestracji i uśredniania potencjałów wywołanych patrz np. [6,7]). Fala P1 jest zaś pierwszym komponentem widocznym $\mathrm{w}$ potencjale wywołanym zarówno przez bodźce „standard”, jak i bodźce „dewiant” (rycina 1) [7].
Fala N1

Drugą ze składowych egzogennych widoczną w korowych odpowiedziach wywołanych jest fala o latencji 90-110 ms określana mianem N1 (rycina 1). Duża litera „N” oznacza, że składowa N1 posiada ujemną polarność, a cyfra „1”, że jest to pierwsza ze składowych pojawiająca się w odpowiedzi korowej.

Podobnie jak falę P1 również składową N1 można najłatwiej zaobserwować w odpowiedziach na bodźce "standard” i „dewiant” prezentowane w klasycznej formie procedury „oddball” (rycina 2A).

Fala N1 charakteryzuje się czołowo-centralną dystrybucją i nie ma jednego dobrze zdefiniowanego generatora [8]. Badania sugerują, że N1 jest załamkiem, w którym zawierają się trzy inne składowe. Dwie $\mathrm{z}$ nich generowane są bilateralnie w korze słuchowej. Miejsce generacji trzeciej ze składowych jest wciąż niejasne, a dostępne dane wskazują na lokalizację generatora w modalnie niespecyficznych polach korowych [8]. Wszystkie trzy składowe fali N1 reagują istotnie na zmianę fizycznej energii dostarczanej przez bodziec, która pozostaje niezmienna przynajmniej przez krótki czas. A zatem włączenie bodźca na cichym tle lub ciągły ton, który co jakiś czas zmienia częstotliwość, będą wywoływać zmianę fali N1 [8]. Tego typu właściwości świadczą o tym, że fala N1 odzwierciedla mechanizmy w korze słuchowej wrażliwe na zmianę [8]. Badania wskazują również, 
że załamek N1 nie jest jedynie wskaźnikiem samej zmiany (nieważne jakiej), lecz może być markerem korowej aktywności związanej ze zmianą w samej reprezentacji bodźca. Niewykluczone też, że N1, a zwłaszcza jego składowa określana mianem N1b, odzwierciedla rodzaj kierowanego uwagą procesu „pierwszego sczytania” informacji z analizatora czuciowego. N1 może też być reprezentantem tworzenia się śladów pamięciowych prezentowanego bodźca, który jest następnie używany w procesie porównywania ze śladami różnych innych bodźców. Tak czy inaczej obecność komponentu N1 jest jednoznacznym fizjologicznym dowodem, że informacja o bodźcu dotarła do kory słuchowej [8].

Fala P2

Do składowych sensorycznych (egzogennych) CAEP zalicza się także fala określana mianem P2, występująca z latencją 150-250 ms (rycina 1). Jak wskazuje sama nazwa, jest ona drugim (po P1) dodatnim komponentem widocznym w odpowiedzi wywołanej. Falę P2, podobnie jak wcześniej opisywane sensoryczne składowe słuchowych potencjałów korowych, najłatwiej wywołać i zaobserwować w odpowiedziach na bodźce prezentowane w procedurze „oddball”, zarówno na bodźce „standard”, jak i „dewiant" [9].

Postuluje się, że generatorem fali P2 jest między innymi górna powierzchnia płata skroniowego. Generator tam umieszczony zlokalizowany jest jednak najprawdopodobniej bardziej do przodu niż generator fali N1, który znajduje się w tzw. planum temporale leżącym w centrum zakrętu skroniowego [9]. Oprócz wymienionego generatora wskazuje się również na inne miejsca powstawania fali P2. Niektórzy za generator załamka P2 uważają na przykład niespecyficzny polisensoryczny system zlokalizowany w boczno-czołowej części górno-skroniowej powierzchni kory słuchowej [10] lub wskazują na rolę, jaką w generacji fali odgrywa aktywująca część tworu siatkowatego [11].

Niewiele jest danych na temat funkcjonalnego znaczenia fali P2. Opisując falę P2, większość naukowców zwraca często uwagę na fakt, że komponent ten występuje w odpowiedzi korowej zawsze bezpośrednio po fali N1. Postulują oni, że każda $\mathrm{z}$ fal reprezentuje inny proces przetwarzania informacji: fala N1 - ocenę odbieranej (docierającej) informacji akustycznej, a fala P2 - transmisję odebranej (rozpoznanej) informacji do innych kolejnych pól korowych w celu jej dalszej oceny [9].

\section{Kompleks N1-P2}

Załamek P2 z reguły rozpatruje się jako komponent odrębny od N1. Fala P2 może być bowiem eksperymentalnie oddzielona od występującego wcześniej załamka N1 [12]. Udowodniono między innym, że fala P2 zmienia się z wiekiem, niezależnie od poprzedzającego załamka [13], jak również ma inną dystrybucję na powierzchni głowy niż N1 [14]. Zmiany widoczne w fali P2 bardzo często współwystępują jednak z N1. Oba komponenty rozpatruje się więc niekiedy łącznie jako jeden kompleks zwany N1-P2.

Publikacje, w których fale N1 i P2 opisuje się jako kompleks, wskazują na więcej niż jedno źródło generacji tego komponentu. Niektóre z lokalizacji generatorów

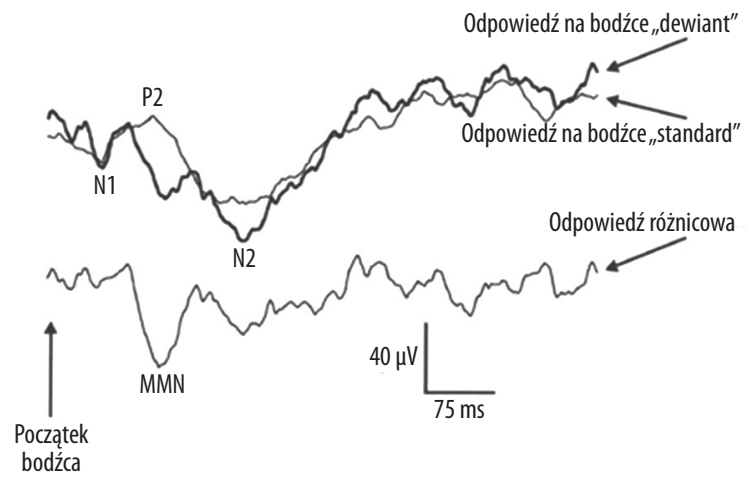

Rycina 3. Górna część rysunku zawiera przykład nałożonych na siebie słuchowych potencjałów korowych zarejestrowanych w odpowiedzi na bodźce częste „standard” (cienka linia) oraz rzadkie „dewiant” (gruba linia) prezentowe w pasywnej procedurze „oddball” (ang. passive oddball paradigm). Poniżej odpowiedź różnicowa wraz z widoczną falą niezgodności (ang. mismatch negativity, MMN) obliczona poprzez matematyczne odjęcie od odpowiedzi na bodźce rzadkie odpowiedzi na bodźce częste

Figure 3. The upper part of the figure shows the superimposed average evoked potentials to standard (thick line) and deviant (thin line) stimuli presented in the passive oddball procedure. Below the differential potential with mismatch negativity wave (MMN) calculated by the mathematical subtraction of the evoked potentials to standard stimuli from the evoked potentials to deviant stimuli

przynajmniej po części pokrywają się ze źródłami będącymi miejscami generacji pojedynczych fal N1 oraz P2. Tak jest, na przykład, z górną i położoną blisko kory słuchowej płaszczyzną zakrętu skroniowego - planum temporale. W obszarze tym za pomocą zarówno metod analizy lokalizacji źródeł potencjałów wywołanych, jak i źródeł pól magnetycznych zsynchronizowanych z podawanymi bodźcami, kilkakrotnie lokalizowano dipole (generatory) kompleksu N1-P2 ustawione stycznie do płaszczyzny struktury [8,15-17]. Inne badania, wykorzystujące analizę źródła potencjałów rejestrowanych za pomocą siatki gęsto rozłożonych elektrod wszczepianych bezpośrednio do kory, wskazują z kolei, że kompleks N1-P2 może być wyjaśniony przez pionowo i stycznie zorientowane generatory położone w pierwotnej korze słuchowej lub promieniowo zorientowane dipole w drugorzędowej korze słuchowej [18].

Podobnie jak w przypadku fal P1 czy P2, niewiele jest prac mówiących o funkcjonalnym znaczeniu kompleksu N1-P2. Niektóre z nich wskazują, że kompleks ten może być bioelektrycznym markerem procesów związanych z przetwarzaniem czasowych lub spektralnych aspektów języka mówionego [19]. Wykazano bowiem, że fala N1-P2 ulega zmianom pod wpływem treningu mającego na celu zwiększenie percepcji tzw. długości odsunięcia dźwięczności [20] (ang. voice onset time, VOT [21]). Jest to parametr fonetyczny określający czas pomiędzy rozpoczęciem wymawiania spółgłoski zwartej a jej plozją, czyli drganiem strun głosowych. VOT jest zatem kluczowy podczas rozpoznawania mowy [22]. Zmiany widoczne w N1-P2 
wywołane treningiem parametru VOT wydają się zaś wskazywać, że komponent ten związany jest $\mathrm{z}$ neuroplastycznością kory słuchowej, a obserwowane zmiany odzwierciedlają poprawę opracowywania informacji werbalnej na jej poziomie [21].

\section{Fala niezgodności}

Za ostatni z komponentów zaliczanych do składowych egzogennych CAEP uważana jest tzw. fala niezgodności (ang. mismatch negativity, MMN) także charakteryzująca się ujemną polarnością (np. [3], rycina 3). Klasyfikując falę niezgodności, trzeba zaznaczyć, że niektórzy badacze opisujący słuchowe potencjały korowe zaliczają tę składową do grupy potencjałów endogennych (związanych ze zdarzeniem; patrz np. [23]). Kontrowersje dotyczące przyporządkowania odpowiedzi wynikają między innym z długiej latencji fali, która wskazuje ewidentnie, iż komponent MMN związany jest z późniejszym w czasie procesem endogennym. $Z$ drugiej strony wiele danych potwierdza, iż fala niezgodności w znaczącym stopniu zależy od fizycznej charakterystyki bodźców wyzwalających odpowiedź i stąd $z$ reguły zaliczana bywa (zwłaszcza przez audiologów) do składowych egzogennych (przegląd patrz np. [1,3]).

Oprócz kontrowersji związanych z klasyfikacją komponentu MMN, fala niezgodności jest również ciekawa ze względu na specyficzny paradygmat badawczy, który służy do jej wywoływania. Jest nim jedna z wielu wersji klasycznego paradygmatu „oddball”, określana mianem pasywnej procedury „oddball” (ang. passive oddball paradigm), (rycina 2B; opis szczegółowy patrz np. [7,24,25]). Charakteryzuje się ona tym, iż osoba badana uczestniczy biernie - jak wskazuje sama nazwa - w rejestracji CAEP, tzn. nie słucha aktywnie prezentowanych stymulacji złożonych z bodźców „standard” oraz „dewiant”, lecz podczas prezentacji ogląda na przykład film lub czyta gazetę. Ma to na celu odwrócenie jej uwagi od prezentowanych bodźców $[6,26]$. Sygnał zarejestrowany podczas tego badania opracowuje się bardzo podobnie jak podczas klasycznego badania. Po zakończeniu rejestracji uzyskuje się również uśrednione odpowiedzi na bodźce z każdej kategorii - bodźce „standard” oraz „dewiant”. Co bardzo ważne, fala MMN pojawia się w odpowiedzi korowej w zakresie latencji, w którym widoczne są również składowe N1 i P2. Wyekstrahowanie komponentu wymaga więc zastosowania specjalnej techniki podczas analizy sygnałów. Polega ona na odjęciu od odpowiedzi uśrednionej dla wszystkich bodźców „dewiant”, uśrednionej odpowiedzi na bodźce „standard”. Pozwala to otrzymać tak zwany potencjał różnicowy lub krzywą różnicową, na której z reguły widoczna jest już fala niezgodności, którą można dalej analizować (rycina 3) [27].

Badania dystrybucji przestrzennej fali MMN w testach $\mathrm{z}$ użyciem magnetoencefalografii, rejestracji elektrofizjologicznych z wnętrza mózgu u zwierząt i ludzi, jak również oparte na wnioskach płynących ze skutków uszkodzeń ośrodkowego układu nerwowego u ludzi pokazują, że generator fali MMN znajduje się najprawdopodobniej w korze słuchowej. Wykazano jednak, że dokładna lokalizacja generatora MMN zmienia się wraz ze zmianą fizycznych aspektów (częstotliwości, czasu trwania czy głośności) oraz złożoności (werbalne vs. niewerbalne) bodźców prezentowanych $\mathrm{w}$ trakcie pasywnej procedury „oddball. Niektóre z ostatnich badań pokazują również, że oprócz kory słuchowej w generacji fali MMN aktywny i istotny udział ma również kora czołowa. Sądzi się jednak, że pełni ona rolę automatycznego przełącznika uwagi z odbieranych powtarzających się bodźców „standard” na pojawiający się nagle bodziec „dewiant”. Są również dane, zebrane zwłaszcza w trakcie badań na zwierzętach, które wskazują, że w powstawaniu MMN biorą udział podkorowe generatory zlokalizowane we wzgórzu i hipokampie [28].

W odniesieniu do funkcjonalnego znaczenia MMN, uważa się, że fala ta odzwierciedla zdolność ośrodkowej części układu słuchowego do porównania reprezentacji bodźca „dewiant” z reprezentacją neuronalną bodźców „standard" występujących wcześniej i zapisanych w pamięci krótkotrwałej. MMN jest więc reprezentantem bioelektrycznym automatycznego procesu niedopasowania pomiędzy sensoryczną aktywnością neuronalną wywołaną przez bodźce „dewiant” a śladem pamięciowym związanym z bodźcami „standard”. Bodziec „dewiant” nie aktywuje jednak nowych dróg wejściowych, tak jak to ma miejsce w przypadku fali N1. Z uwagi na fakt, że zmiana pomiędzy bodźcem „dewiant” i „standard” dotyczy wyłącznie cech bodźca, MMN odzwierciedla proces oddzielnego i niezależnego przetwarzania różnych cech bodźca, gdyż w danym momencie bodziec „dewiant” różni się od bodźca „standard” właśnie daną i określoną cechą. Cechą różniącą oba bodźce i będącą niespójną może być intensywność [29], inny czas trwania bodźców [30], zmiana we wzorcu podawania bodźców spowodowana przez niewielkie przesunięcia (wcześniejsze pojawienie się w sekwencji) bodźca „dewiant” [31]. Ponadto warunki, w jakich rejestruje się największą odpowiedź MMN, wskazują, że proces, który prowadzi do powstawania fali MMN, zachodzi automatycznie i poza świadomością. Jak wspomniano wcześniej, falę MMN o największej amplitudzie rejestruje się bowiem wtedy, gdy osoba badana nie zwraca bezpośredniej uwagi na pojawiające się stymulacje bodźce „standard” oraz „dewiant” [32].

\section{Związane ze zdarzeniem (endogenne) składowe słuchowych potencjałów korowych - charakterystyka, miejsce generacji, znaczenie funkcjonalne oraz schemat(-y) doświadczalne najczęściej wykorzystywane do generacji poszczególnych fal}

\section{Fala N2}

Oprócz potencjałów sensorycznych drugą dużą grupą słuchowych potencjałów korowych stanowią związane ze zdarzeniem endogenne słuchowe potencjały korowe. Pierwszym z komponentów silnie zależnym od zmiennych endogennych, takich jak uwaga, trudność zadania czy znaczenie bodźca, jest fala określana jako N2. Fala N2 jest negatywnym komponentem widocznym w słuchowych odpowiedziach korowych z latencją w zakresie 250-300 ms (rycina 1) i podobnie jak fala N1 osiąga maksymalną amplitudę w okolicach czołowo-centralnych [33].

Fala N2, podobnie jak N1 czy P2, nie ma jednego wyraźnego generatora. Uważa się, że komponent ten jest składową trzech innych różnych odpowiedzi. Pierwszą 
ze składowych określa się mianem N2a i opisuje jako falę o dystrybucji czołowo-centralnej. Generator fali N2a jest bardzo rozległy i obejmuje korę słuchową, płat czołowy i najprawdopodobniej hipokamp. Komponentowi N2a przypisuje się kilka znaczeń funkcjonalnych. Uważa się między innymi, że jest on związany z detekcją nowości lub niespójności w prezentowanych bodźcach. W przypadku zadania „oddball”, w trakcie którego najlepiej można wygenerować i zaobserwować ten komponent, odzwierciedla on natomiast różnicę pomiędzy neuronalnym pobudzeniem wywołanym przez bodziec "dewiant” a sensoryczno-pamięciową reprezentacją bodźca „standard”. Komponent N2a jest więc najprawdopodobniej związany z analizą cech bodźców słuchowych w pamięci sensorycznej. Według niektórych badaczy wyodrębnianie składowej N2a ma jednak w chwili obecnej raczej znaczenie historyczne. Uważa się bowiem, że N2a to jedynie opisywana wcześniej składowa egzogennych słuchowych odpowiedzi korowych - fala niezgodności [33].

Fala N2a nakłada się na drugą z wyodrębnianych składowych N2 zwaną falą N2b [1]. Składowa N2b ma również czołowo-centralną dystrybucję. W przeciwieństwie do fali N2a generator tej fali lokalizuje się w przednim zakręcie obręczy [33], korze czołowej oraz górnej korze skroniowej [34]. Cechą charakterystyczną fali N2b jest wyraźna ekspresja komponentu w tzw. zadaniach Go-Nogo (rycina 2D). Polegają one na różnicowaniu, podawanych $\mathrm{w}$ parach i $\mathrm{z}$ reguły $\mathrm{z}$ tym samym prawdopodobieństwem, dwóch różniących się jakąś cechą bodźców tej samej kategorii (np. tonów różniących się częstotliwością czy sylab różniących się jakimś fonetycznym elementem, np. długością odsunięcia dźwięczności, czyli parametrem VOT). Podczas wykonywania zadania należy udzielić odpowiedzi (z reguły ruchowej), jeśli drugi z bodźców prezentowanych w parze jest taki sam jak pierwszy (np. jest tonem o tej samej częstotliwości) - „warunek Go”. Natomiast, kiedy drugi z bodźców jest inny niż pierwszy (np. jest tonem o wyższej częstotliwości), należy powstrzymać się od odpowiedzi („warunek Nogo”). Sądzi się, że powstawanie N2b związane jest więc $\mathrm{z}$ procesem hamowania odpowiedzi behawioralnej na bodziec „Nogo”, konfliktem pomiędzy odpowiedziami na bodźce prezentowane w zadaniu Go-Nogo czy też kontrolą przed popełnieniem błędu w zadaniu [34].

Czasami opisuje się także trzecią ze składowych N2 zwaną N2c. Dystrybucja tej fali jest inna w zależności od bodźców wywołujących odpowiedź. W przypadku bodźców słuchowych ma ona, tak jak dwie poprzednie składowe, również dystrybucję czołowo-centralną. Wyraźna składowa N2c pojawia się także w odpowiedziach na bodźce prezentowane w procedurze „oddball”. Jest wówczas większa w odpowiedziach na bodźce "dewiant” niż na bodźce „standard”. Wydaje się więc, że funkcjonalnie składowa N2c reprezentuje proces pewnej klasyfikacji bodźca, podczas gdy pozostałym dwóm komponentom przypisuje się rolę bioelektrycznych markerów procesów detekcji niespójności [33]. Jak twierdzą niektórzy badacze, procesy detekcji niespójności, których odzwierciedleniem byłyby składowe N2a i N2b, odgrywają rolę w uruchamianiu odruchu orientacyjnego [35].
Fala P3 (P300)

Fala P3 to kolejny korowy komponent endogenny zaliczany do grupy potencjałów związanych ze zdarzeniem. Od momentu odkrycia fali P3 w 1963 roku [36], komponent ten jest chyba najczęściej opisywaną i badaną odpowiedzią wśród składowych endogennych potencjałów korowych (przegląd patrz np. $[37,38]$ ). W odpowiedzi wywołanej fala P3 występuje, jak sama nazwa wskazuje, jako trzecia z kolei, dodatnia składowa. Fala $\mathrm{P} 3$ ma z reguły postać wyraźnej, dobrze wyrażonej (o dużej amplitudzie) odpowiedzi, której jedną z cech charakterystycznych jest brak specyficzności modalnej. Oznacza to, że fala P3 może zostać wywołana przez stymulacje o różnej modalności: wzrokowej, słuchowej lub dowolnie innej (patrz np. [39]). Latencja, z jaką fala P3 pojawia się w odpowiedzi wywołanej, waha się w granicach 220-380 ms [3]. Cechą charakterystyczną komponentu P3 jest również jego polimorficzność. Składowa P3 występuje bowiem dość często w postaci dwóch załamków określanych mianem: P3a i P3b (rycina 1) [40].

Miejsce generacji fali P3 nadal nie zostało do końca sprecyzowane. Falę o największej amplitudzie rejestruje się z reguły w odprowadzeniach zlokalizowanych wzdłuż linii środkowej przebiegającej przez okolice centralno-ciemieniowe. Ponadto w trakcie rejestrowania załamka P3 obserwuje się jednoczesną aktywność w wielu, często nakładających się na siebie rejonach mózgu. Obszary te zlokalizowane są $\mathrm{z}$ reguły w korze czołowej lub skroniowej. Aktywność związana z generacją fali P3 była rejestrowana również w skroniowo-ciemieniowej korze asocjacyjnej. Inne pola, które związane są z generacją P3, lokalizuje się w pierwszorzędowej korze słuchowej i wielomodalnej korze asocjacyjnej $[41,42]$.

Schematem stymulacji wykorzystywanym do rejestracji fali P3, podobnie jak w przypadku wielu pozostałych składowych korowych, jest także procedura „oddball”. W przeciwieństwie do fali niezgodności (MMN) do wyzwalania składowej P3 stosuje się jednak najczęściej nie pasywny tylko tzw. aktywny wariant procedury „oddball” (ang. active oddball paradigm) (rycina 2C). Tak jak w przypadku pasywnej procedury „oddball”, polega on na prezentacji w pseudolosowej kolejności bodźców „standard” i bodźców „dewiant”, z tym że osoba badana aktywnie uczestniczy w wykonywanym badaniu. Jej zadaniem jest zwracanie uwagi na bodźce „dewiant”. Uwaga na bodźce kierowana jest $\mathrm{z}$ reguły albo poprzez odpowiedź ruchową udzielaną w odpowiedzi na rzadziej pojawiające się bodźce albo poprzez aktywne zliczanie liczby zaprezentowanych bodźców „dewiant” $[6,43,44]$. Tak jak w pozostałych wersjach badania „oddball”, także w wersji aktywnej schematu badawczego potencjały wywołane uzyskiwane są poprzez oddzielne uśrednienie odpowiedzi na bodźce „dewiant” i bodźce „standard”. Odpowiedzi te są następnie porównywane ze sobą [6]. Cechą charakterystyczną badania CAEP wykorzystującego aktywną procedurę „oddball” jest to, że w odpowiedziach na bodźce „standard” dominują przede wszystkim składowe sensoryczne (egzogenne): fale P1, N1 i P2. W odpowiedziach na bodźce „dewiant” oprócz wymienionych składowych rejestruje się również składową P3 (rycina 1) [36,43]. 
Od wielu lat wśród specjalistów toczą się dyskusje, a czasami wręcz spory, dotyczące funkcjonalnego znaczenia oraz procesu (-ów), które leżą u podłoża generacji fali P3 (patrz: $[44,45]$. Obecnie istnieje kilka często odmiennych teorii opisujących funkcjonalne znaczenie tego załamka $[43,46,47]$. Mówi się także o wspomnianych wcześniej dwóch załamkach fali P3 - P3a i P3b, przypisując każdemu $\mathrm{z}$ nich związek $\mathrm{z}$ innym procesem neuronalnym. Załamek P3a, według niektórych, odzwierciedla bowiem proces związany z pewnego rodzaju automatyczną reakcją orientacyjną [48] lub nieświadomym przełączeniem uwagi na „coś nowego" $[49,50]$. Kiedy uwaga osoby badanej jest natomiast zaangażowana $\mathrm{w}$ bardziej świadomy proces i badany w kontrolowany sposób rozpoznaje oraz uznaje, że to, co „słyszy, widzi lub czuje”, jest w jakimś sensie dla niego ważne, w słuchowych potencjałach korowych rejestruje się drugi z załamków - P3b opisywany przed laty jako P300, a ostatnio właśnie jako P3 [36]. W związku z powyższym załamkowi P3b przypisuje się bardzo często rolę markera świadomego procesu rozpoznania i kategoryzacji bodźców o istotnym znaczeniu. Niektórzy sugerują jednak, że proces związany z P3b ma jednak miejsce po podjęciu decyzji, co należy zrobić z bodźcem właśnie rozpoznanym i zaklasyfikowanym jako istotny. Jak pokazują bowiem niektóre badania, fala P3b często pojawia się w odpowiedzi wywołanej później niż odpowiedź ruchowa na bodziec „dewiant”. Jak twierdzi Verleger (1997) [47], odzwierciedla ona więc swoisty proces zamknięcia (ang. closure) całej ewaluacji bodźca, a więc jego dyskryminację, rozpoznanie i klasyfikację [51]. Latencja P3b byłaby zaś parametrem, który pozwalałby - w sposób relatywny niejako - zmierzyć, jak długo ten proces trwa w czasie [52].

Fala N400 (składowa semantyczna, potencjał semantyczny)

Ostatnią ze składowych słuchowych potencjałów korowych, wymienianą bardzo często w grupie komponentów endogennych, jest ujemna fala, której szczyt (maksymalna amplituda) występuje z latencją ok. $400 \mathrm{~ms}$ po podaniu bodźca wywołującego odpowiedź korową, zwana odpowiednio falą N400, składową lub potencjałem semantycznym [53]. Komponent ten charakteryzuje się centralno-ciemieniową dystrybucją na powierzchni głowy $[50,54,55]$.

Jakkolwiek, podobnie jak w przypadku fali P3, uważa się, że załamek N400 posiada wiele aktywujących się jednocześnie i rozsianych generatorów [48], wiele technik, takich jak zapis EEG z powierzchni głowy, zapis sygnałów bioelektrycznych $\mathrm{z}$ elektrod zaimplementowanych bezpośrednio do mózgu, badania pacjentów $\mathrm{z}$ uszkodzonym mózgiem czy rejestracje magnetoencefalografem wskazują przede wszystkim na lewy, lecz także na prawy płat skroniowy jako miejsca będące najprawdopodobniej źródłem fali N400 [56].

Cechą charakterystyczną fali N400, wyróżniającą ją spośród pozostałych składowych potencjałów korowych, są przede wszystkim specyficzne warunki, w jakich rejestruje się tę odpowiedź. Komponent N400 w najprostszy sposób można wywołać w paradygmacie, który określa się jako semantyczny (rycina 2E) (patrz również: [25]). Polega on na tym, że osobie badanej w losowej kolejności prezentuje się dwa rodzaje zdań: 1) poprawne semantycznie zdania na przykład typu: „Posmarowałem(-łam) bułkę masłem”, w których zakończenia bardzo dobrze pasują do wcześniejszego kontekstu i istnieje duże prawdopodobieństwo, że prezentowane aktualnie zdanie zakończy się w oczekiwany przez słuchacza sposób i 2) niepoprawne semantycznie zdania typu: „Posmarowałem(-łam) bułkę biurkiem”, których zakończenia nie pasują do wcześniejszego kontekstu, a prawdopodobieństwo takiego zakończenia zdań jest dosyć małe. Rejestrując odpowiedź bioelektryczną mózgu na każdy rodzaj zdań (z reguły zapisuje się i uśrednia odpowiedzi na ostatnie odpowiednio spójne bądź niespójne słowo każdego z prezentowanych zdań) można zauważyć, że o ile poprawne semantycznie zdania nie wywołują lub wywołują z reguły niewielką odpowiedź N400, o tyle istnieje duże prawdopodobieństwo, że komponent N400 o ujemnej polarności i latencji w okolicy około $400 \mathrm{~ms}$ zarejestrowany zostanie w odpowiedzi na ostatnie słowo z drugiej kategorii (niespójnych) zdań [57].

Prowadząc przez lata liczne badania, wykazano, że słowa kończące zdania różniące się stopniem kontekstualnego dopasowania i prawdopodobieństwem występowania w danym języku wywołują fale N400 o różnej amplitudzie. Wyrazy o dużym prawdopodobieństwie pojawienia się na końcu danego zdania generują komponent N400 o niskiej, natomiast słowa kończące o małym prawdopodobieństwie wystapienia (o dużej tzw. „niespójności semantycznej”) - falę N400 o wysokiej amplitudzie [48,55]. Wykazano również, że latencja fali N400 zmienia się też wraz ze wzrostem złożoności zadania. Im bardziej złożone zdanie, tym dłuższa latencja fali N400. Badając w późniejszych latach zależność fali N400 od różnych czynników, wykazano także, że na istotne zmiany fali N400 ma wpływ nie tyle wystąpienie niespójnego słowa na końcu zdania, lecz w ogóle pojawienie się go w zdaniu, niezależnie od miejsca, w którym się ono znajduje w całej sentencji (ang. semantic unexpectancy). Można powiedzieć, że znaczenie ma pewne zaskoczenie, że akurat taki a nie inny wyraz pojawił się w zdaniu, a nie konkretne miejsce jego pojawienia się. Zgodnie $\mathrm{z}$ tym obecnie uważa się, że na falę N400 nie ma wpływu semantyczna relacja końcowego słowa $\mathrm{z}$ uprzednim kontekstem (semantyczna niespójność, ang. semantic unrelatedeness) [58], lecz raczej naruszenie semantyki zdania w ogóle [3].

Wykazano również, że w generacji fali N400 istotną rolę może odgrywać proces dyskryminacji fonologicznej bodźca. Jak pokazują badania Connolly i wsp. (1992) [55] z wykorzystaniem fonologicznego maskowania (polegało ono na tym, że ostatnie słowo w zdaniach wywołujących falę N400 odtwarzane było razem $\mathrm{z}$ innym słowem), latencja N400 wzrasta, jeżeli zastosowany masker jest dobrze dopasowany pod względem fonologicznym do bodźców (słów), w odpowiedzi na które generowana jest odpowiedź bioelektryczna. W innych badaniach udowodniono z kolei, że amplituda fali N400 ulega redukcji, gdy wyrazy poprzedzające słowa krytyczne (wyzwalające składową N400) są do nich podobne (np. rymują się z nimi). Taki efekt wskazuje również, że fala N400 nie jest specyficzna wyłącznie dla analizy znaczenia słów (analizy na poziomie semantycznym), lecz może mieć związek także z przetwarzaniem fonologicznym [59-61].

W literaturze można znaleźć znacznie więcej prac pokazujących wpływ jeszcze innych czynników na zmianę amplitudy 
i latencji fali N400. Wszystkie one wskazują wyraźnie na związek fali $\mathrm{N} 400$ z przetwarzaniem informacji na wysokim poziomie i zależność od różnych (w większości semantycznych) cech języka. Niektórzy badacze zakładają ponadto, że są to raczej procesy zachodzące świadome i niewykluczone, że mające miejsce już po odkodowaniu znaczenia słowa (np. procesy integracyjne weryfikowania poprawności przekazu słownego, analizy postleksykalnej) [62,63].

\section{Cel pracy}

Przez większą część XX wieku zarówno egzogenne, jak i endogenne słuchowe potencjały korowe nie były rutynowo używane w badaniach klinicznych [64]. Dotyczyło to zwłaszcza badań noworodków lub małych dzieci. Przyczyną takiego stanu rzeczy była między innymi duża zmienność międzyosobnicza i międzygrupowa tych odpowiedzi. Rozwój nowoczesnych metod analizy i zmiany w metodologii spowodowały, że badania nad wykorzystaniem CAEP w klinice zaczęły pojawiać się od połowy lat 90 . Od tego momentu opracowywane są też coraz to nowsze metody rejestracji oraz oceny poszczególnych składowych słuchowych potencjałów korowych, począwszy od nowych parametrów opisujących komponenty, bardziej wyrafinowanych paradygmatów wykorzystywanych do wywoływania i rejestracji CAEP, a skończywszy na nowoczesnych metodach analizy źródeł poszczególnych odpowiedzi (przegląd patrz np. $[6,23,25]$ ). Metoda CAEP zaczyna też być wykorzystywana $\mathrm{w}$ wielu różnych dziedzinach nauki, przede wszystkim w medycynie, a zwłaszcza w neurologii [65] czy psychiatrii (np. [66,67]). Za pomocą CAEP próbuje się obiektywnie oceniać funkcjonowanie różnego rodzaju procesów poznawczych w chorobach związanych z nieprawidłowym działaniem ośrodkowego układu nerwowego, takich jak chociażby: epilepsja [68], udar mózgu [69], śpiączka [70], zespół alkoholowy [71], depresja, schizofrenia [66], choroba Alzheimera [72] czy chociażby różnego rodzaju formy demencji [73]. Naturalnym polem klinicznego wykorzystania słuchowych potencjałów korowych pozostaje jednak od lat przede wszystkim audiologia. Wysoką użyteczność metody CAEP wykazano przede wszystkim w ocenie funkcjonowania różnego rodzaju ośrodkowych procesów słuchowych (patrz np. $[19,74,75])$, czy w badaniach i diagnostyce nieprawidłowych procesów przetwarzania słuchowego, językowego czy poznawczego, będących przyczyną różnego rodzaju zaburzeń, na przykład zaburzeń uczenia się [76-78].

Celem niniejszej pracy jest przedstawienie różnego rodzaju form wykorzystania słuchowych potencjałów korowych w ocenie funkcjonowania oraz diagnostyce klinicznej ośrodkowych procesów słuchowych. W pracy przedstawiono szczegółową charakterystykę oraz liczne przykłady wykorzystania najczęściej opisywanych w literaturze sensorycznych (egzogennych) oraz związanych ze zdarzeniem (endogennych) składowych słuchowych potencjałów korowych. Przy opisach dotyczących klinicznego zastosowania poszczególnych składowych CAEP przedstawiono ponadto istotne zalety i wady procedur opartych na rejestracji opisywanych komponentów oraz zwrócono uwagę na istotne aspekty techniczne, które należy brać pod uwagę podczas badań CAEP u specyficznych grup pacjentów.
Kliniczne zastosowanie oraz ocena przydatności sensorycznych (egzogennych) składowych słuchowych potencjałów korowych w diagnostyce ośrodkowych procesów słuchowych

\section{Fale P1, N1 i P2}

Ocena stanu funkcjonalnego dróg podkorowych oraz korowych ośrodków związanych $z$ przetwarzaniem stuchowym

Jak wspomniano wcześniej, do grupy sensorycznych (egzogennych) słuchowych potencjałów korowych zalicza się trzy składowe - falę P1, N1 oraz P2. Są one generowane na wyższych piętrach analizy informacji akustycznej - we wstępujących drogach słuchowych biegnących ze wzgórza do kory słuchowej (fala P1) $[3,4]$ oraz w pierwszorzędowej i asocjacyjnej korze słuchowej (fala N1, P2) [8]. Pierwszym i zarazem podstawowym zastosowaniem składowych sensorycznych słuchowych potencjałów korowych w audiologii klinicznej jest więc ocena stanu funkcjonalnego ośrodków słuchowych, w których te odpowiedzi są generowane. Oceniając samą obecność komponentów P1, N1 czy P2, można stwierdzić, czy bodźce słuchowe prezentowane osobie badanej docierają i czy w ogóle zostały zdetekowane na poziomie kory słuchowej [2]. Obecność fal P1, N1, P2 świadczy o tym, że neurony kory słuchowej odebrały prezentowany bodziec oraz zainicjowały jego przetwarzanie. Analizując natomiast poszczególne parametry (amplitudę, latencję oraz morfologię) rejestrowanych składowych sensorycznych, można wnioskować o stanie funkcjonalnym (np. liczbie pobudzonych włókien, szybkości przewodzenia) w drogach transmitujących informację słuchową ze wzgórza do kory słuchowej jak również o efektywności i sprawności działania pierwszorzędowej i asocjacyjnej kory słuchowej (np. jak duże pobudzenie w korze wywołują prezentowane bodźce słuchowe czy też jak szybko kora odpowiada na prezentowane stymulacje).

\section{Ocena progów styszenia}

Od połowy lat 60. sensoryczne składowe CAEP wykorzystywane są również do oceny progów słyszenia [2,3]. Co więcej, w obiektywnych badaniach czułości słuchu, testy elektrofizjologiczne $\mathrm{z}$ wykorzystaniem sensorycznych składowych CAEP uważane są przez niektórych za bardzo dobrą alternatywę dla stosowanej najczęściej w tym celu metody słuchowych potencjałów wywołanych pnia mózgu (ang. auditory brainstem responses, ABR). Metoda ta pozwala na rejestrację i ocenę odpowiedzi bioelektrycznych generowanych w drogach i niższych ośrodkach związanych z przetwarzaniem informacji akustycznej (nerwie słuchowym, jądrach podkorowych) [2]. Olbrzymią przewagą metody CAEP nad ABR jest na przykład znacznie krótszy czas samego badania. Bardzo istotna jest również amplituda fal P1, N1 czy P2, która z reguły jest znacząco większa (ok. 10-30 razy) niż składowych pniowych, takich jak fala III czy V, dzięki czemu znacznie łatwiej oceniać odpowiedzi. Z uwagi na fakt, że sensoryczne składowe potencjałów korowych są znacznie większe pod względem amplitudy odpowiedzi, są także mniej podatne na zakłócenia i szum elektromagnetyczny generowany przez różnego rodzaju urządzenia elektroniczne. Zaletą odpowiedzi sensorycznych CAEP jest również duża zmienność i reaktywność tych fal na zmiany fizycznych parametrów stosowanych 
stymulacji akustycznych. Dotyczy to między innymi głośności bodźców. Wykazano, że w większości przypadków głośność bodźców o różnej częstotliwości, przy której rejestruje się jeszcze odpowiedź bioelektryczną (sensoryczne komponenty CAEP), jest jedynie o $10 \mathrm{~dB}$ wyższa niż rzeczywiste progi słyszenia dla częstotliwości wyznaczanych metodami behawioralnymi $[1,2,79]$. Stosując metodę sensorycznych składowych potencjałów korowych, można więc w bardzo dokładny i precyzyjny sposób oszacować czułość słuchu dla różnego rodzaju stymulacji. Olbrzymią zaletą tej metody jest również to, że sensoryczne komponenty korowe mogą być wywoływane bodźcami bardziej specyficznymi częstotliwościowo i znacznie dłuższymi niż na przykład bodziec typu „trzask” w ABR. Pozwala to wyznaczyć progi słyszenia dla bodźców o dłuższym czasie trwania oraz zarówno tych o niskich, jak i o wysokich częstotliwościach. Tego typu właściwość wynika między innymi ze znacznie mniejszej zależności odpowiedzi generowanych na poziomie kory słuchowej od synchronizacji bodźca [80]. Nie trzeba bowiem podawać krótkich, szybko narastających i opadających oraz o szerokim spektrum częstotliwościowym bodźców, jak np. trzask w metodzie ABR, ażeby pobudzić i zsynchronizować dużą liczbę neuronów. W przypadku wyżej położonych ośrodków bardziej specyficzną i optymalną stymulacją stają się natomiast bardziej złożone tony czy werbalne stymulacje. Oprócz możliwości wyznaczenia progów słyszenia, kolejną zaletą badań opartych na sensorycznych składowych potencjałów korowych jest więc sprawdzenie, jak przebiega korowa detekcja bardziej złożonych bodźców, na przykład bodźców werbalnych - sylab czy całych wyrazów [2].

Niestety metoda sensorycznych potencjałów korowych nie jest pozbawiona wad. W przeciwieństwie do ABR, sensoryczne odpowiedzi korowe zależą od stanu funkcjonalnego osoby badanej. Dotyczy to zwłaszcza młodszych pacjentów (noworodków czy małych dzieci), u których potencjały sensoryczne trudno zarejestrować lub zanikają one podczas snu lub w sedacji [81-83]. Od dawna wiadomo, że rejestracja we śnie lub sedacji jest bardzo przydatna, a czasami wręcz konieczna, aby uniknąć wpływu różnego rodzaju artefaktów, które generowane są w sygnale EEG pod wpływem na przykład ruchu oczu lub ciała osoby badanej i maja duży wpływ na jakość rejestrowanych odpowiedzi [84]. Ocena progów słyszenia $\mathrm{z}$ wykorzystaniem metody sensorycznych składowych potencjałów korowych ogranicza się więc w zasadzie wyłącznie do grona osób dorosłych. W przypadku dzieci lub noworodków prowadzenie rejestracji tego typu potencjałów wymaga natomiast dodatkowego monitoringu snu, co znacznie podraża koszty i wymaga personelu wykwalifikowanego w ocenie EEG.

Ocena zmian aktywności neuronalnej i neuroplastyczności w ośrodkach korowych zwiazanych $z$ przetwarzaniem sluchowym u osób $z$ niedostuchem

Ocena progów słyszenia różnego rodzaju bodźców akustycznych czy badanie stanu funkcjonalnego wyższych ośrodków słuchowych to tylko jeden z przykładów wykorzystania sensorycznych składowych CAEP w diagnostyce i ocenie funkcjonowania ośrodkowych procesów przetwarzania słuchowego. Innym przykładem zastosowania klinicznego tego rodzaju odpowiedzi jest wykorzystanie komponentów P1, N1 czy P2 do oceny chwilowych zmian aktywności neuronalnej lub długotrwałych zmian plastycznych w ośrodkach korowych związanych z przetwarzaniem słuchowym, powstałych pod wpływem utraty słuchu czy też związanych z rehabilitacją słuchową.

Martin i wsp. (1999) [19] przeprowadzili badania, w których sensoryczne składowe potencjałów korowych wywoływane były bodźcami werbalnymi (sylabami) o słyszalności zmodyfikowanej przez maskujący w tle szum. Bodźce maskowano na przykład szumem przefiltrowanym górno-, dolno- lub szerokopasmowym filtrem. Maskowanie szumem o różnym spektrum miało na celu symulować u zdrowych osób utratę słuchu odpowiednio na wysokich, niskich lub w zakresie wszystkich częstotliwości. Wykazano, że im bardziej zredukowana pod wpływem zastosowanego szumu była słyszalność poszczególnych sylab, tym większa była redukcja amplitudy i wydłużona latencja fali N1. Potwierdza to funkcjonalne znaczenie fali N1 związane z korową detekcją dźwięków oraz pokazuje, że pod wpływem zakłócającej stymulacji zmianie ulegała aktywność kory słuchowej związanej z opracowywaniem stosowanych sylab.

Podobne wyniki, już nie u osób zdrowych tylko u pacjentów z odbiorczym uszkodzeniem słuchu, uzyskali również inni autorzy. Na przykład Kraus i wsp. (1995) [85] w swoich badaniach wykazali, że u badanych przez nich pacjentów zmianie ulegała nie tylko fala N1, lecz także pozostałe sensoryczne składowe odpowiedzi korowej - fale P1 i P2. We wszystkich komponentach odnotowano wydłużenie latencji i obniżenie amplitudy rejestrowanych odpowiedzi.

Badania pokazujące wykorzystanie sensorycznych składowych potencjałów korowych do monitoringu zmian aktywności kory słuchowej pod wpływem detekcji różnego rodzaju bodźców werbalnych u osób z niedosłuchem odbiorczym prowadzili też Martin i wsp. (2007) [86]. Sensoryczne komponenty korowych potencjałów wywołanych rejestrowano $\mathrm{w}$ odpowiedzi na mające różne brzmienie samogłoski /u/. Zmiana brzmienia samogłosek wywołujących odpowiedzi odbywała się poprzez manipulację częstotliwością tzw. drugiego formantu samogłoski, czyli drugiego maksimum w przebiegu obwiedni widmowej samogłoski [87]. Maksimum to było przesuwane w zakresie częstotliwości od $0 \mathrm{~Hz}$ do $1200 \mathrm{~Hz}$. Dzięki temu osoba badana słyszała prezentowane bodźce jako czyste samogłoski /u/ lub - w zależności od stopnia zmiany formantu - jako tak zwany dyftong /ui/, czyli dźwięk składający się z zespolenia dwóch czysto brzmiących samogłosek /u/ oraz /i/. Każda z prezentowanych samogłosek o różnej częstotliwości formantu generowała dwa kompleksy sensorycznych odpowiedzi P1-N1-P2: 1) będący odpowiedzią na włączenie bodźca i 2) tzw. kompleks ACC (ang. acoustic change complex), który - jak pokazują wcześniejsze badania - jest bioelektryczną reakcją właśnie na zmianę częstotliwości formantu [88]. Wykazano, że amplituda kompleksu ACC ulegała stopniowemu zmniejszeniu, aż do zmiany częstotliwości formantu wynoszącej ok. $38 \mathrm{~Hz}$. Udowodniono tym samym, że neuronalna detekcja zmiany formantu w korze badanej osoby $\mathrm{z}$ niedosłuchem odbiorczym odbywała się aż do tego poziomu.

W literaturze można spotkać również kilka prac wykorzystujących metodę sensorycznych składowych CAEP 
do oceny wpływu niedosłuchu przewodzeniowego na aktywność kory słuchowej [89-91]. W badaniach tych wykazano wydłużoną latencję wszystkich składowych sensorycznych rejestrowanych u pacjentów z tego rodzaju niedosłuchem. Tecchio i wsp. (2000) [90] w badaniach z wykorzystaniem magnetoencefalografii, czyli metody polegającej na rejestracji i analizie sygnału magnetycznego mózgu powiązanego z EEG, oceniali ponadto zmiany plastyczne zachodzące po zabiegu operacyjnym, którego celem było usunięcie tego rodzaju niedosłuchu. Wykazano $\mathrm{w}$ nich istotne zwiększenie po operacji amplitudy magnetycznej składowej sensorycznych słuchowych potencjałów korowych (odpowiednika komponentu N1 w potencjałach bioelektrycznych), tzw. składowej N1m. Tego typu zmiana, jak wskazują autorzy, wskazuje na istotne zwiększenie korowej reprezentacji dla tonów wywołujących odpowiedzi słuchowe. Co więcej, badania te powtórzono po kilku tygodniach, rejestrując podobną amplitudę odpowiedzi, wykazując jednocześnie, że mające miejsce zmiany plastyczne utrzymują się w czasie.

Wykorzystując składowe sensoryczne potencjałów wywołanych, można wykazać również, jak szybka jest korowa reorganizacja kory słuchowej pod wpływem deprywacji. Jak pokazują badania Vasama i wsp. (1995) [92] oraz Pontona i wsp. (1996) [93], już u osób z nagłym jednostronnym niedosłuchem obserwuje się istotne zmiany fali N1 polegające na obniżeniu jej amplitudy i wydłużeniu latencji. Stosując metodę sensorycznych składowych potencjałów korowych, zmiany w obrębie kory wynikające $z$ braku dopływu informacji słuchowej można też oceniać z dłuższej perspektywy. Jak wykazali Vasama i wsp. (1994) [89] w badaniach z użyciem magnetoencefalografu, $\mathrm{u}$ dzieci z wrodzonym jednostronnym niedosłuchem oraz z ośrodkowymi efektami deprywacji (mierzonymi na podstawie wyników testów behawioralnych oceniających wyższe funkcje słuchowe) bardzo często obserwuje się także istotne opóźnienie w kształtowaniu się prawidłowej morfologii magnetycznego odpowiednika sensorycznej odpowiedzi korowej fali N1 - komponentu N1m.

Ocena zmian plastycznych $w$ ośrodkach korowych zwiąanych $z$ przetwarzaniem stuchowym wynikajacych $z$ zastosowania aparatów słuchowych

Rejestracje sensorycznych składowych CAEP można również wykorzystać do oceny funkcjonowania ośrodkowych procesów słuchowych u osób, u których odbiór informacji akustycznej wspomagany jest aparatem słuchowym $[94,95]$. Do chwili obecnej przeprowadzono kilka badań, w których sensoryczne komponenty potencjałów korowych rejestrowane były u dzieci z różnym stopniem niedosłuchu, korzystających lub niekorzystających z aparatów słuchowych (patrz np. [96,97]). Wyniki tych badań są bardzo zbieżne $z$ neuronalną detekcją i tym, czy prezentowane bodźce wywołujące komponenty sensoryczne CAEP były słyszane czy nie. Wówczas kiedy dzieci nie były wyposażone w aparaty słuchowe, nie rejestrowano bowiem żadnej ze składowych sensorycznych fali - P1, N1 czy P2. Z kolei u dzieci z założonymi aparatami w potencjałach wywołanych rejestrowano wyraźną składową P1 oraz następującą po niej ujemną składową N2. Istotną poprawę jakości odpowiedzi korowych po zastosowaniu aparatów słuchowych opisują także Korczak i wsp. (2005) [94] w swoich badaniach przeprowadzonych z udziałem osób dorosłych. Idzie ona $\mathrm{w}$ parze $\mathrm{z}$ poprawą behawioralnej dyskryminacji dźwięków, zwłaszcza u osób z głębokim ubytkiem słuchu. Po założeniu aparatów widać przede wszystkim wzrost amplitudy, skrócenie latencji i poprawę morfologii odpowiedzi. Faktem, na który zwracają uwagę autorzy pracy, jest jednak duża zmienność fal rejestrowanych u poszczególnych osób. Może to wynikać z tego, że aparaty w różny sposób zmieniają akustykę sygnału, co z kolei ma przełożenie na wzorzec wywołanych odpowiedzi [95]. Rejestrując potencjały wywołane u osób wyposażonych w aparat słuchowy i chcąc wyciągać poprawne wnioski z uzyskanych odpowiedzi, dobrze jest więc rozumieć, jak sygnał odbierany z otoczenia przetwarzany jest przez aparat [98]. Trzeba ponadto pamiętać, że pomimo iż sygnał $z$ otoczenia zostaje wzmocniony, parametry odpowiedzi u pacjentów z utratą słuchu nigdy nie będą takie jak u osób prawidłowo słyszących [94].

Ocena zmian plastycznych w ośrodkach korowych związanych $z$ przetwarzaniem słuchowym wynikajacych $z$ zastosowania implantów ślimakowych

Sensoryczne składowe słuchowych potencjałów korowych znajdują również zastosowanie w ocenie korzyści uzyskiwanych dzięki zastosowaniu u osób niedosłyszących implantów ślimakowych. Badania mające na celu znalezienie źródła kompleksu N1-P2 pokazują, że generator bioelektryczny tego komponentu u pacjentów $\mathrm{z}$ wszczepionym implantem ślimakowym zlokalizowany jest - podobnie jak u zdrowych osób słyszących - w korze słuchowej [99]. Wykazano również, że latencja i amplituda fal N1 i P2 u osób, które mają dużą korzyść z implantu, jest podobna jak u osób normalnie słyszących. Tego efektu nie widać natomiast u osób, u których implant nie przyniósł oczekiwanych korzyści $[100,101]$. Ponadto zwraca się uwagę na fakt, że zwłaszcza składowa P2 jest komponentem, na podstawie którego najlepiej można oceniać korzyści $\mathrm{w}$ przetwarzaniu słuchowym po zastosowaniu implantu ślimakowego [102].

Rejestracje składowych słuchowych potencjałów korowych u pacjentów z wszczepionym implantem można wykonywać, podając bodźce słuchowe wywołujące odpowiedzi zarówno akustycznie - na przykład drogą powietrzną przez głośnik z wolnego pola, jak i wywoływać je elektrycznie, stymulując bezpośrednio implant. W tym drugim przypadku trzeba mieć jednak na uwadze, że rejestrowane odpowiedzi będą miały, z racji bezpośredniej stymulacji elektrycznej, skrócone latencje w porównaniu z komponentami wywoływanymi metodą tradycyjną. Po drugie podawanie bodźców przez implant wiązać się będzie $\mathrm{z}$ synchronizowanym $\mathrm{z}$ bodźcem artefaktem bioelektrycznym widocznym w sygnale EEG. W większości przypadków taki artefakt będzie miał postać krótkich impulsów o radiowej częstotliwości, a będzie on najbardziej widoczny w elektrodach EEG otaczających magnes implantu. W zależności od typu implantu artefakt ten nie powinien uniemożliwiać jednak oceny poszczególnych składowych potencjałów wywołanych w wielu pozostałych odprowadzeniach. Wykonując badania z wykorzystaniem sensorycznych składowych potencjałów korowych, warto więc wykonywać rejestrację $\mathrm{z}$ wielu (min. 19) elektrod $[86,103]$. 
W trakcie rejestracji potencjałów wywołanych warto również używać możliwie jak najkrócej trwających bodźców, aby artefakt związany z bodźcem kończył się jeszcze przed rozpoczęciem neuronalnej odpowiedzi na ten bodziec (potencjałem wywołanym) $[93,104,105]$. Innym sposobem jest ustawienie tzw. elektrody odniesienia (elektrody, w stosunku do której obliczane jest napięcie prądu rejestrowane z pozostałych odprowadzeń EEG) wzdłuż linii izoelektrycznej artefaktu (miejsca na powierzchni głowy znajdującego się na tym samym poziomie co magnes implantu), co również powinno znacząco zmniejszyć artefakt [106].

Podczas oceny wyników badań i odróżniania właściwych odpowiedzi korowych od artefaktu warto też zwrócić uwagę na fakt, że niektóre składowe odpowiedzi (zwłaszcza fala N1, a także P2; patrz np. [9,25,107]) zależą (zwiększają amplitudę) od wzrostu natężenia uwagi osoby, u której prowadzona jest rejestracja. Z uwagi na fakt, że artefakt jest elementem „sztucznie” generowanym przez zewnętrzne urządzenie, zwiększenie poziomu uwagi nie będzie miało wpływu na jego wielkość. Inną przydatną wskazówką jest polaryzacja otrzymywanych odpowiedzi. Artefakty generowane przez implant będą miały często odwróconą polaryzację w przeciwieństwie do składowych potencjałów wywołanych związanych z aktywnością neuronalną kory słuchowej. Właściwa ocena otrzymywanych odpowiedzi i znajomość tego typu niuansów technicznych jest szczególnie przydatna podczas rejestracji sensorycznych komponentów CAEP wywoływanych bodźcami werbalnymi, zwłaszcza u osób z obustronnie wszczepionymi implantami [86].

Mówiąc o istotnych aspektach technicznych, które należy brać pod uwagę podczas badań CAEP u pacjentów $\mathrm{z}$ implantem, warto na koniec wspomnieć, że implanty ślimakowe - podobnie jak aparaty słuchowe - zmieniają sygnał akustyczny odbierany z otoczenia. A zatem wszelkie ustawienia implantów (liczba kanałów, kontrola poziomu głośności i inne parametry) mogą mieć wpływ na jakość uzyskiwanych odpowiedzi korowych [103]. Prowadząc badania $\mathrm{z}$ wykorzystaniem słuchowych potencjałów korowych, trzeba zatem kontrolować wszystkie te czynniki [2].

Ocena zmian aktywności oraz neuroplastyczności w obrębie korowych ośrodków słuchowych pod wpływem treningu stuchowego

Oprócz opisanych powyżej sposobów aplikacji sensorycznych składowych potencjałów korowych, pomiar i ocena tych odpowiedzi mogą być wykorzystane do monitorowania zmian w przetwarzaniu korowym dźwięków, wywołanych różnego rodzaju rehabilitacją i treningiem słuchowym. Tremblay i wsp. (2001) [108] rejestrowali sensoryczne składowe CAEP u osób poddanych treningowi, w którym należało różnicować sylaby różniące się parametrem VOT (opis parametru patrz wcześniej). Wykazano, że amplituda kompleksu N1-P2 [3,25] wzrastała znacząco u osób, które poprawnie nauczyły się różnicować prezentowane $\mathrm{w}$ czasie treningu sylaby $\mathrm{z}$ różnym VOT-em. Podobne wyniki otrzymali Atienza i wsp. (2002) [109] oraz Tremblay i wsp. (1998) [110], którzy oceniali zmiany komponentów słuchowych potencjałów korowych pod wpływem treningu słuchowego polegającego na różnicowaniu złożonych wzorców słuchowych albo bodźców werbalnych zarówno u osób zdrowych, jak i korzystających z aparatów słuchowych czy implantów. Po zakończeniu treningu najwyraźniejsze zmiany obserwowano zwłaszcza w przypadku składowej P2 oraz innej składowej egzogennej - fali niezgodności (MMN). Amplituda fali P2 ulegała wyraźnemu zwiększeniu, a w przypadku fali MMN skracała się latencja tej fali czy też zwiększało się pole powierzchni obliczane pod uzyskiwaną odpowiedzią (inny sposób parametryzacji odpowiedzi korowych (opis metody patrz np. [6,25]). Co również bardzo istotne, odnotowano, że zmiany opisane powyżej występowały przed behawioralną poprawą percepcji dźwięków, na których oparty był trening [109,110]. Pokazuje to, że za pomoca metody CAEP można obiektywnie ocenić korzyści $\mathrm{z}$ treningu, nawet przed zaobserwowaniem zmian behawioralnych.

Inne sposoby wykorzystania sensorycznych składowych słuchowych potencjałów korowych

Sensoryczne składowe słuchowych potencjałów korowych (fale P1, N1 czy P2) były też wykorzystywane do obiektywnej (niezależnej od czynników egzogennych) oceny różnych psychoakustycznych procesów czy stanu różnych wyższych funkcji słuchowych. Na podstawie zmian komponentów sensorycznych wyznaczano na przykład: progi detekcji przerwy między kolejnymi bodźcami słuchowymi [111-113], progi jednousznej lub obusznej rozdzielczości czasowej [114,115], próg maskowania obusznego [116] czy też oceniano umiejętność segregacji ciągów bodźców akustycznych [117]. We wszystkich przypadkach są to procesy zależne od wielkości progu rozdzielczości czasowej.

Te oraz inne wyższe procesy słuchowe były wielokrotnie badane zarówno w populacji osób zdrowych, jak i w populacjach osób z różnymi dysfunkcjami o charakterze słuchowym, np. u osób z neuropatia słuchowa [118], czy z zaburzeniami uczenia się [119]. We wszystkich tych przypadkach rejestrowane sensoryczne składowe potencjałów korowych były nieprawidłowe, miały obniżona amplitude lub wydłużoną latencję.

Komponenty sensoryczne CAEP wykorzystuje się też bardzo często jako metodę obiektywnej diagnostyki ośrodkowych procesów słuchowych u pacjentów, u których nie moga być wykonane tradycyjne testy behawioralne, na przykład u dzieci czy dorosłych z zaburzeniami komunikacji [2].

W niektórych tego rodzaju zaburzeniach (np. u dzieci z problemami w uczeniu się) sensoryczne składowe potencjałów korowych były też wykorzystywane do oceny efektów różnego rodzaju treningów [119]. Za pomocą metod opartych na sensorycznych składowych CAEP sprawdzano między innymi efektywność: treningu rozpoznawania słów w szumie [120], treningu polegającego na słuchowym segmentowaniu słów [121] czy treningu muzycznego [122]. We wszystkich tych przypadkach amplitudy poszczególnych sensorycznych komponentów potencjałów korowych ulegały również zwiększeniu, a latencje skróceniu.

Fala niezgodności - mismatch negativity (MMN)

Kolejny komponent słuchowych potencjałów wywołanych zaliczany do składowych egzogennych stanowi fala niezgodności (ang. mismatch negativity, MMN). Biorąc 
pod uwage miejsce generacji oraz funkcjonalne znaczenie fali MMN (opis patrz powyżej oraz [123]), postuluje się cztery główne potencjalne zastosowania tego komponentu w ocenie i diagnostyce klinicznej ośrodkowych procesów słuchowych: 1) fali MMN jako „dobrego” reprezentanta tego, jak kora słuchowa (gdzie znajduje się główny generator fali [28]) odpowiada na zmianę w odbieranych bodźcach słuchowych jakiejś konkretnej cechy; 2) fali MMN jako obiektywnego markera pomiaru czasu trwania krótkotrwałej pamięci słuchowej; 3) komponentu MMN jako wskaźnika poziomu automatycznej uwagi zaangażowanej w detekcję zmiany dźwięku i 4) fali niezgodności - MMN jako indeksu aktywności neuronów odpowiedzialnych za podtrzymywanie w krótkotrwałej pamięci reprezentacji słuchowych bodźców specyficznych językowo (np. fonemów).

Fala niezgodności (MMN) - marker detekcji zmiany w charakterystyce (cechach) odbieranych bodźców stuchowych

Jeżeli chodzi o pierwsze $\mathrm{z}$ zastosowań, to według Risto Näätänena (2000) [123] na podstawie amplitudy i latencji MMN można wnioskować odpowiednio, jak wiele neuronów zaangażowanych było $\mathrm{w}$ detekcję zmiany w jakiejś cesze słyszanych bodźców słuchowych oraz jak szybko ta detekcja zaszła. Dotychczas przeprowadzono wiele badań, w których wykazano, że zmiana w charakterystyce (cesze) bodźca, która powoduje pojawienie się fali MMN, może dotyczyć najróżniejszych jego aspektów: częstotliwości (np. [124-126]), głośności (np. [127-129]), lokalizacji w przestrzeni słuchowej $[130,131]$, jak również czasowych aspektów słuchowej stymulacji, takich jak: czas trwania bodźca [132], narastanie [133] odstępu od poprzedzającego bodźca (ang. inter-stimulus interval, ISI) [134], kolejności w serii stymulacji [135] i zmiany wielu innych cech (przegląd patrz: [26]). Ponadto detekcja zmiany w cechach bodźca dotyczy zarówno bodźców prostych takich jak tony [26], jak i bardziej złożonych stymulacji akustycznych takich jak akordy czy bodźce werbalne (fonemy, sylaby, słowa) (np. [136-138]), a nawet zmiany w zakresie struktury gramatycznej zdań [139]. Wiadomo również, że amplituda i latencja fali MMN zależą od wielkości zmiany, jaka zachodzi nie tylko w samym bodźcu, lecz także w strukturze bodźców, w jakiej jest on zakorzeniony [26].

Monitorując i oceniając zmiany fali MMN wywoływanej w pasywnej procedurze „oddball”, w której to prezentowane są bodźce różniące się dowolną cechą, i zmieniając stopniowo różnicę (kontrast) pomiędzy prezentowanymi bodźcami (bodźcem „standard” i bodźcem „dewiant”), można wyznaczać progi detekcji dla najróżniejszych cech bodźca (cech, którymi manipulujemy). Wykazano, że wyznaczane progi detekcji są bardzo zbliżone do progów oszacowywanych za pomocą procedur behawioralnych. Lang i wsp. (1990) [140] w swoich badaniach, stosując procedurę MMN, wykazali na przykład, że progi detekcji zmiany w częstotliwości bodźca u osób bardzo dobrze różnicujących bodźce pod względem tej cechy mogą być wyznaczone $\mathrm{z}$ dokładnością nawet do $12 \mathrm{~Hz}$. U osób tych, podając bodźce różniące się częstotliwością o taką wartość, rejestrowano bowiem falę MMN.
Fala niezgodności (MMN) - marker pomiaru czasu trwania krótkotrwałej pamięci słuchowej

Kolejnym z potencjalnych zastosowań fali MMN w ocenie wyższych funkcji słuchowych, na którą zwraca uwagę Näätänen (2000) [123], jest pomiar czasu trwania krótkotrwałej pamięci słuchowej. W trakcie trwania pasywnej procedury „oddball” odbiór kilku bodźców „standard” następujących po sobie powoduje bowiem wytworzenie pewnego rodzaju sensorycznego śladu pamięciowego - pobudzenie reprezentacji neuronalnej specyficznej dla danej cechy bodźca. Ważny jest tutaj również czas czy też odstęp pomiędzy kolejnym stymulacjami. Gdy do kory w odpowiednim czasie dociera informacja wywołana przez bodziec „dewiant”, sytuacja nieco się zmienia. Reprezentacja neuronalna związana z powtarzającą się stymulacją (bodźcem „standard”) jest wciąż aktywna, co prowadzi niejako do automatycznej detekcji zmiany (reprezentacje neuronalne bodźca „standard” i „dewiant” nie pokrywają się bowiem dokładnie ze sobą) i powstania aktywności bioelektrycznej, która rejestrowana jest na powierzchni głowy jako fala MMN. Wykazano, że u młodych zdrowych osób odstęp pomiędzy kolejnymi bodźcami (ang. inter-stimulus interval, ISI) w pasywnej procedurze „oddball”, przy którym fala MMN może być wciąż zarejestrowana, wynosi około 10 sek. [141-143]. Czas ten w niewielkim stopniu maleje wraz z wiekiem $[144,145]$. Jak wskazuje Näätänen (2000)[123], odstęp pomiędzy bodźcami, przy którym możemy wciąż zarejestrować falę MMN, jest więc czasem trwania krótkotrwałej pamięci słuchowej. Czas ten zgadza się z danymi opublikowanymi wcześniej przez Cowana (1984)[146]. Pomiar obecności fali MMN podczas pasywnej procedury „oddball” proponuje się jako potencjalnie obiektywne „narzędzie” do wyznaczania czasu trwania krótkotrwałej pamięci słuchowej $[147,148]$. Tego typu zastosowanie kliniczne wykorzystywane było dotychczas na przykład u pacjentów cierpiących na chroniczny alkoholizm $[149,150]$ czy różnego rodzaju choroby neurodegeneracyjne takie jak choroba Alzheimera [151,152]. We wszystkich tych grupach pacjentów wykazano znaczące skrócenie czasu trwania pamięci krótkotrwałej.

Fala niezgodności (MMN) - marker poziomu zaangażowania automatycznej uwagi stuchowej

Fala MMN może być również wskaźnikiem uwagi zaangażowanej w detekcję zmiany dźwięku [123]. Proces detekcji zmiany zachodzący na poziomie kory słuchowej może bowiem uruchamiać mechanizm nieświadomego przełączenia uwagi ku potencjalnie ważnym bodźcom w środowisku słuchowym, na które aktualnie uwaga nie jest skierowana $[127,153]$. Dowodzą tego wyniki wielu badań, które pokazują, że w krótkim czasie po słuchowej aktywacji kory możemy również zarejestrować aktywność neuronalną w okolicach czołowych mózgu (np. [154-157]). Potwierdzeniem tego faktu jest też większa liczba składowych komponentów, które tworzą odpowiedź bioelektryczną, jaką jest fala MMN. Jak wspomniano wcześniej, oprócz podstawowej składowej fali MMN generowanej w korze słuchowej (górnym zakręcie skroniowym) wyróżnia się również składową, której generator umiejscawia się w okolicach czołowych $[124,125,127,153]$. Komponent ten byłby odzwierciedleniem aktywności przednich obszarów mózgu w procesie przełączenia uwagi, mającym miejsce 
po detekcji zmiany w cesze bodźca - procesie zachodzącym w korze słuchowej [153]. Innym dowodem istnienia składowej czołowej MMN, przytaczanym przez niektórych badaczy, jest to, że zmiany w dźwiękach nagle pojawiających się w środowisku słuchowym, które wywołują przekierowanie uwagi powodujace fale MMN i zaburzaja wykonywanie w danej chwili zadania, powodują oprócz fali MMN wygenerowanie innego komponentu słuchowych potencjałów korowych - fali P3a (opis patrz: Wprowadzenie). Komponent ten uważany jest również za marker procesu mającego początek w okolicach czołowych, który polegałby na przekierowaniu uwagi na bodziec wyróżniający się w słuchanej aktualnie sekwencji $[5,158,159]$ (przegląd patrz: [160]). Na proces automatycznego przełączania uwagi i zaangażowanie struktur czołowych w generację fali MMN wskazują także badania autonomicznego systemu nerwowego, w których to wykazano, że po wystąpieniu fali MMN ma miejsce spowolnienie rytmu serca i pojawia się odpowiedź galwaniczna skóry [133] (patrz także: [161]). Wiadomo również, że zastosowanie małej ilości alkoholu etylowego, który wpływa na procesy czołowe, także oddziałuje na czołową składową fali $\mathrm{MMN}$, nie majac wpływu na składową generowaną w korze słuchowej [162].

Po podsumowaniu powyższych faktów, wydaje się, że analiza zmienności fali MMN, a zwłaszcza jej czołowej składowej, może stanowić narzędzie pozwalające oceniać stan automatycznych procesów uwagi słuchowej.

Fala niezgodności - MMN jako indeks stanu funkcjonalnego śladów pamięciowych dla bodźców specyficznych językowo (fonemów)

Jak wspomniano wcześniej, komponent MMN może być generowany w odpowiedzi na zmiany nie tylko w obrębie prostych bodźców słuchowych, lecz także wyzwalany przez różnice $\mathrm{w}$ cechach złożonych bodźców werbalnych, np. fonemów, sylab, słów, wyrazów czy zdań [139]. W związ$\mathrm{ku} \mathrm{z}$ powyższym kolejnym potencjalnym zastosowaniem fali niezgodności wydaje się wykorzystanie składowej jako markera aktywności neuronalnej czy też indeksu stanu funkcjonalnego śladów pamięciowych związanych $\mathrm{z}$ analizą bodźców specyficznych językowo. Potwierdzaja to na przykład prace Näätänena i Alho (1997) [32] (zobacz także: [163-165]), którzy przeprowadzili badania z wykorzystaniem magnetoencefalografii wśród Finów i Estończyków, u których fala niezgodności MMN wywoływana była w odpowiedzi na samogłoski wspólne lub nie dla obu nacji. Samogłoski te prezentowane były zgodnie z pasywna procedurą „oddball”. Wykazano, że samogłoska „õ” występująca wyłącznie w języku estońskim, w sytuacji gdy prezentowana była jako bodziec „dewiant”, wywoływała falę MMN o znacznie większej amplitudzie u Estończyków niż u Finów. Jako bodziec „standard” prezentowano natomiast samogłoskę „e" wspólną dla obu nacji. Z kolei kiedy jako bodziec „dewiant” prezentowano samogłoski „o" lub „ö”, wspólne dla Finów i Estończyków, fale MMN w odpowiedzi na tego rodzaju bodźce miały bardzo zbliżone amplitudy u osób każdej z narodowości. W trakcie badań analizowano również wewnątrzmózgowe źródła (dipole) fal MMN zmieniających się pod wpływem zmian w prezentowanych fonemach. Wykazano, że generator magnetycznego odpowiednika fali MMN (tzw. fala MMNm), który podlegał największym zmianom (wzmocnieniu) pod wpływem zastosowanych manipulacji językowych, lokalizował się przede wszystkim w polu Wernickego, znajdującym się tylnej korze skroniowej i zaangażowanym, co wiadomo od dawna, w proces rozpoznawania głosek, wyrazów i zdań - tzw. czuciową analizę językową. Podobnych dowodów wskazujących na możliwość wykorzystania fali MMN do monitoringu i badania procesów związanych $\mathrm{z}$ analizą różnic językowych w bodźcach należących do języka ojczystego dostarczyli Cheour i wsp. (1998) [166] oraz Dehaene-Lambertz i Baillet (1998) [137], prowadząc badania na noworodkach. Pokazuje to, że na podstawie zmian w komponencie MMN można badać aspekty przetwarzania językowego również u bardzo małych dzieci. Z kolei Winkler i wsp. (1999) [167] przeprowadzili badania na dorosłych, udowadniając, że falę MMN można również wykorzystać jako indeks do monitoringu procesów sensorycznej pamięci językowej podczas nauki języka obcego. Jak wskazuje Näätänen i wsp. (1999) [168], w korze słuchowej funkcjonują bowiem połączone ze sobą grupy komórek nerwowych stanowiących reprezentacje neuronalne określonych fonemów, które aktywują się w momencie ich odbioru (słuchania). Dzięki temu możliwe jest ich prawidłowe rozpoznanie. W trakcie nauki języka reprezentacje te - w najróżniejszych kombinacjach - pobudzane są cyklicznie. Wykorzystując falę MMN, można badać, jak kształtują się (zmieniają się) te aktywacje w danym momencie oraz w czasie.

Zalety $i$ wady procedur opartych na rejestracji fali niezgodności (MMN), wykorzystywanych podczas badania wyższych funkcji stuchowych

Mówiąc o klinicznym zastosowaniu fali MMN w badaniach ośrodkowych procesów słuchowych, warto wspomnieć o niektórych praktycznych aspektach związanych z tego typu badaniami. Jeżeli chodzi o zalety, to niewątpliwym atutem testów diagnostycznych wykorzystujących falę MMN jest ich niski koszt oraz stosunkowo prosta procedura wykonania. Rejestracja sygnału EEG może być wykonana dosłownie z kilku kanałów. Kolejną olbrzymia zaletą badania MMN jest również to, iż rejestracja fali $M M N$ jest tak naprawdę jednym $\mathrm{z}$ nielicznych narzędzi umożliwiających obiektywną (niezależną od pacjenta) ocene wyższych procesów słuchowych. Co więcej rejestracja fali MMN, jak wspomniano wcześniej, wykonywana może być bez zaangażowania osoby badanej. Pasywna procedura „oddball” lub jej pochodne nie wymagaja motywowania pacjenta czy też angażowania jego uwagi w wykonywane zadanie. Należy tylko biernie słuchać prezentowanych bodźców. Badanie MMN może być więc z powodzeniem wykonywane u bardzo małych dzieci czy tzw. „trudnych pacjentów" - osób, u których ocena tradycyjnymi metodami behawioralnymi jest bardzo trudna lub niemożliwa. Ponadto niektóre prace doświadczalne pokazują, że komponent MMN może znaleźć kliniczne zastosowanie w badaniach różnego rodzaju stanów niepełnej świadomości. Jako predykator szans w odzyskaniu świadomości, falę MMN rejestrowano na przykład u pacjentów w stanie wegetatywnym $[169,170]$. Z kolei w innych pracach była ona wykorzystywana do badania udziału świadomości w różnych stadiach snu. Wykazano w nich między innymi, że fala MMN zanika, gdy poziom świadomości osoby badanej ulega obniżeniu [171]. 
Pomimo wielu potencjalnych zalet i możliwości wykorzystania fali MMN w badaniach ośrodkowych procesów słuchowych, liczni specjaliści zwracają uwagę na istotne ograniczenia w klinicznym wykorzystaniu metody MMN. Dotyczą one wykorzystania metody zwłaszcza w indywidualnych przypadkach $[1,172]$. Dane literaturowe pokazują na przykład, że fala MMN jest bardzo często trudna lub wręcz niemożliwa do zarejestrowania w przypadku zastosowania zbyt łatwych kontrastów w prezentowanych bodźcach słuchowych [1]. Innym ważnym niekorzystnym aspektem rejestracji fali MMN jest duża zmienność indywidualna komponentu MMN oraz jego słaba powtarzalność podczas rejestrowania odpowiedzi [172]. Oznacza to, że pomimo zastosowania takich samych warunków rejestracji, fala MMN bardzo często zanika lub zmieniają się jej parametry (np. obniża amplituda). Jak wspomniano wcześniej, procesy związane z generacją fali MMN przebiegają poza świadomością, trudno więc tak naprawdę ustalić, jaki czynnik (zmienna) wpłynął na obserwowaną zmianę [1]. Wszystko to istotnie utrudnia kliniczną ocenę u badanej osoby. Kolejnym problemem, który wiąże się $\mathrm{z}$ dużą zmiennością fali MMN, jest brak wypracowanych standardów wykonywania badań. Zanim procedura rejestracji MMN będzie mogła być w pełni wykorzystywana klinicznie, konieczne jest ustalenie, jakie mają być optymalne parametry rejestracji, aby uzyskać wyraźne i powtarzalne pomiary. Problemów ze zmiennością pozbawione są badania MMN prowadzone na większych grupach (populacjach) pacjentów, gdzie zmienność indywidualna ma mniejsze znaczenie [1]. Od lat fala MMN jest więc przedmiotem wielu badań u pacjentów z różnego rodzaju zaburzeniami i dysfunkcjami, głównie o podłożu neurologicznym czy psychiatrycznym. Jeżeli chodzi o audiologię, to fala MMN wykorzystywana była przede wszystkim w badaniach pacjentów z implantami ślimakowymi, centralnymi zaburzeniami słuchu, zaburzeniami językowymi oraz zaburzeniami uczenia się (przegląd patrz: [173-175]. Prowadzone były także badania mające na celu ocenę za pomocą MMN zdolności dyskryminacji różnych bodźców słuchowych u pacjentów z odbiorczym niedosłuchem czy też oceniające korzyści z zastosowania aparatów czy implantów ślimakowych $[175,176]$.

\section{Kliniczne zastosowanie oraz ocena przydatności związanych ze zdarzeniem (endogennych) składowych słuchowych potencjałów korowych w diagnostyce ośrodkowych procesów słuchowych oraz procesów poznawczych i językowych}

Fala N2

Pierwszym komponentem zaliczanym do składowych endogennych słuchowych potencjałów korowych jest fala N2. W literaturze naukowej można znaleźć stosunkowo niewiele prac na temat typowo klinicznego wykorzystania tego komponentu. Przegląd dostępnych publikacji pokazuje, że celem większości prowadzonych dotąd badań była przede wszystkim chęć poznania natury samego komponentu N2 (patrz np. $[33,34,177,178]$ ). To warunkuje dalsze pomysły na kliniczną aplikację rejestracji z wykorzystaniem fali N2. Ponadto warto zaznaczyć, iż w znacznej większości dostępnych prac fala N2 bywa $\mathrm{z}$ reguły rozpatrywana nie jako pojedyncza składowa, lecz jej zmiany analizowane są wraz z innymi komponentami CAEP, zarówno egzogennymi, jak i endogennymi (np. [34,68,179]). Trzeba również podkreślić, że większość badań dotyczących składowej N2 CAEP wykonywana była w schematach doświadczalnych wykorzystujących bodźce wzrokowe, a nie słuchowe (przegląd patrz np. [180]). Dostępna obecnie wiedza o charakterystyce i funkcjonalnym znaczeniu fali N2 pozwala traktować tę składową głównie jako bioelektryczny marker świadomego procesu poznawczego, mającego miejsce po wstępnej percepcji bodźca. Jak wspomniano we Wprowadzeniu, falę N2 wiąże się najczęściej z procesem detekcji niespójności [180], procesami egzekutywnymi takimi jak: hamowanie wcześniej przygotowanej odpowiedzi behawioralnej na mający za chwilę pojawić się bodziec, proces wyboru właściwej odpowiedzi na konkretny bodziec, proces kontroli przed popełnieniem błędu czy też proces klasyfikacji bodźca [34].

\section{Fala N2 - kliniczne zastosowanie w neurologii i psychiatrii}

Analiza rozwoju różnego rodzaju metod elektrofizjologicznych w praktyce klinicznej, pokazuje, że metody wykorzystujące ocenę fali $\mathrm{N} 2 \mathrm{z}$ racji specyfiki tego komponentu wydają się stwarzać pewne możliwości, zwłaszcza w gałęziach medycyny, w których szczególne znaczenie ma ocena funkcjonowania procesów poznawczych, a więc przede wszystkim w psychiatrii i neurologii. Przykładem potencjalnego klinicznego zastosowania słuchowej składowej N2 mogą być chociażby badania Papaliagkasa i wsp. (2008) [181], w których zmienność komponentu wykorzystana została do oceny procesów poznawczych u pacjentów z łagodnymi zaburzeniami poznawczymi (ang. mild cognitive impairment, MCI) oraz pacjentów, u których łagodna demencja rozwijała się w ostrzejszą formę dysfunkcji - chorobę Alzheimera. W badaniach tych u osób z MCI wykazano między innymi zwiększoną, w porównaniu z grupą kontrolną osób zdrowych, amplitudę fali N2 oraz wydłużoną latencję fali N2 i komponentu P3, który był także oceniany w tych badaniach. U niektórych pacjentów opisywane badania wykazały ponadto kolejne, coraz bardziej niekorzystne zmiany w rejestrowanych składowych endogennych CAEP (m.in. dalsze wydłużenie latencji N2) po 6 miesiącach, wówczas gdy choroba zaostrzyła się. Papaliagkas i wsp. (2008) [181] oceniali również korelację parametrów fal N2 i P3 z wynikami psychometrycznego testu MMSE (ang. Mini Mental State Examination) służącego do klasyfikacji pacjentów z MCI. Na podstawie uzyskanych wyników autorzy sugerują, że analiza składowych N2 i P3 stanowi bardzo dobre narzędzie neuropsychologiczne do oceny różnych stadiów MCI. Z badań wynika również, że zmiany latencji fali N2 pozwalają nie tylko na lepszą niż test MMSE identyfikację zmian w pamięci u badanych pacjentów, lecz także mogą być potencjalnym predykatorem zaostrzenia się choroby i przejścia jej w ostrzejszą postać - chorobę Alzheimera.

Przykład klinicznego zastosowania fali N2 w diagnostyce niektórych zaburzeń psychiatrycznych pokazują również badania Miyata i in. (1998) [182] przeprowadzone u pacjentów z zaburzeniami obsesyjno-kompulsywnymi (ang. obsessive compulsive disorder, OCD). Wykorzystując słuchową wersję paradygmatu „oddball”, u pacjentów tych stwierdzono między innymi krótszą latencję fali N2 i P3 niż u pacjentów z fobią socjalną oraz osób zdrowych 
z grupy kontrolnej. Na tej podstawie autorzy twierdzą, że test elektrofizjologiczny oparty na N2 mógłby być dobrym narzędziem różnicujących wymienione dwie grupy zaburzeń psychicznych [67].

Inne przykłady badań, w których zmiany samej fali N2 lub wraz z innymi składowymi endogennymi, generowanymi w klasycznej procedurze „oddball”, wykorzystywano do ceny funkcji poznawczych stanowią badania osób chorych na depresję [183], epilepsję [184] czy migrenę [185]. We wszystkich tych badaniach obserwowano nieprawidłowości dotyczące fali N2. Polegały one przede wszystkim na wydłużeniu jej latencji, ale niekiedy widoczny był również wzrost amplitudy kompleksów P2-N2 czy też N2P3, czyli komponentów, w których fala N2 i P2 oraz N2 i P3 rozpatrywane są jako jedna składowa. Wszystkie te zmiany wskazywały na upośledzenie funkcji poznawczych.

Interesujący przykład klinicznego zastosowania fali N2 stanowią również badania [186] dotyczące osób z zespołem nadpobudliwości ruchowej (ang. attention deficyt hyperactivity disorder, $\mathrm{ADHD}$ ). W badaniach tych fala $\mathrm{N} 2 \mathrm{wy}-$ woływana była za pomocą drugiego $\mathrm{z}$ często stosowanych podczas rejestracji fali N2 schematów doświadczalnych, jakim jest paradygmat Go-Nogo (opis patrz powyżej). Zadanie polegało na różnicowaniu poprzez odpowiedź ruchową (naciskanie przycisku) dwóch rodzajów tonów o innej częstotliwości. Wykazano, że w zadaniu tym osoby z ADHD popełniały znacząco więcej tzw. commission errors (błędów polegających na udzieleniu odpowiedzi ruchowej) w próbach Nogo, które tego nie wymagały. Tego typu błędom towarzyszyło wydłużenie się latencji fali N2. Oprócz zmian fali N2, wykazano również wydłużenie latencji oraz obniżenie amplitudy fali P3, która również była oceniana. Za pomoca specjalnych algorytmów analizy źródła rejestrowanych potencjałów wywołanych w badaniach lokalizowano i oceniano ponadto aktywność generatorów fal o zmienionych parametrach. U osób z ADHD lokalizowały się w prawej grzbietowo-bocznej korze czołowej oraz tylnym zakręcie obręczy oraz miały zredukowną aktywność. Co ciekawe, różnice w parametrach fal pomiędzy osobami z ADHD a osobami zdrowymi, które stanowiły grupę kontrolną, dotyczyły składowych generowanych nie tylko w próbach Nogo, lecz także w próbach Go wymagających naciskania przycisku. W próbach tych osoby $\mathrm{z}$ ADHD popełniały z kolei więcej tzw. omission errors (błędów ominięcia, czyli braku odpowiedzi w sytuacji, kiedy jest ona wymagana), czemu towarzyszyła generacja fal N2 o znacznie zwiększonej amplitudzie. Uzyskane wyniki dotyczace fali N2 potwierdzaja rezultaty obserwowane $w$ innych o wiele liczniejszych badaniach behawioralnych (np: [187-190]; przegląd patrz: [191]) oraz elektrofizjologicznych (wykorzystujących głównie wzrokową wersję testu Go-Nogo) (np. [192,193]), świadczące o dysregulacji u osób z ADHD procesów hamowania odpowiedzi ruchowej na odbierane bodźce. Na podstawie przedstawionych badań można powiedzieć, że polegałaby ona na opóźnionym lub w ogóle na rozpoczęciu hamowania wcześniej przygotowanej odpowiedzi ruchowej w reakcji na bodźce tego niewymagające (efekt N2 widoczny w próbach Nogo) lub/oraz nadmiernym hamowaniu odpowiedzi w momencie, kiedy nie jest to konieczne (efekt widoczny w próbach Go). Za procesy te odpowiadają rejony czołowe mózgu, których nieprawidłowe działanie wykazała także analiza źródła zmienionych potencjałów wywołanych. Wydaje się, że test elektrofizjologiczny oparty na fali N2 może wkrótce stać się narzędziem pomocnym w ocenie funkcji egzekutywnych, stosowanym w diagnostyce i różnicowaniu osób z ADHD oraz innymi zaburzeniami. Z punktu widzenia audiologii może być to przydatne na przykład w różnicowaniu dzieci z zespołem nadpobudliwości ruchowej i dzieci z ośrodkowymi zaburzeniami słuchu, które to zaburzenia bardzo często współwystępują, a diagnostyka różnicowa obu dysfunkcji stanowi wciąż istotny problem (patrz np. [194]).

Fala N2 - przykłady potencjalnych klinicznych zastosowań $w$ audiologii

Jeżeli chodzi o przykłady typowo klinicznego zastosowania fali N2 w audiologii, to trudno znaleźć choćby jedną pracę badawczą, w której komponent N2 rejestrowany w zadaniach typowo słuchowych analizowany był samodzielnie.

Stosując pasywną wersję słuchowej procedury „oddball”, Koravand i wsp. (2012) [179] rejestrowali składowe egzogenne i endogenne CAEP u dzieci w wieku 9-10 lat $\mathrm{z}$ różnym stopniem niedosłuchu i porównywali $\mathrm{z}$ wynikami dzieci zdrowych dobranych pod względem wieku. U dzieci z niedosłuchem wykazano niewielki wzrost amplitudy fali P1 oraz znaczącą redukcję amplitudy i wydłużenie latencji fali N2 w porównaniu z grupą dzieci zdrowych. Autorzy nie obserwowali natomiast żadnych różnic pomiędzy obiema badanymi grupami w zakresie fali MMN. Jak wnioskują Koravand i wsp. (2012) [179], wyniki ich badań pokazują, że deprywacja słuchowa o różnym stopniu prowadzi do opóźnień rozwojowych w obrębie ośrodkowego układu nerwowego na różnych poziomach przetwarzania informacji słuchowej, zarówno percepcyjnym, jak i poznawczym. Co ciekawe, dzieci z niedosłuchem są pomimo tego zdolne do prawidłowego wytworzenia mechanizmów pozwalających na poprawne różnicowanie bodźców słuchowych.

Za pomoca badań elektrofizjologicznych, w których rejestrowano składowe CAEP, w tym komponent N2, próbowano oceniać także wpływ sekwencyjnej implantacji na dojrzewanie oraz realizacje procesów ośrodkowych. Sparreboom i in. (2014) [195] przeprowadzili badania $\mathrm{z}$ wykorzystaniem tzw. elektrycznych słuchowych potencjałów korowych (ang. electrically evoked auditory cortical responses, EACR; odpowiedzi bioelektryczne mózgu wyzwalane bodźcami elektrycznymi a nie akustycznymi) u małych dzieci z wszczepionymi dwoma implantami słuchowymi: pierwszym uruchomionym $\mathrm{w}$ wielu około dwóch lat i drugim wszczepionym po około trzech latach. Zarejestrowane EACR porównywano $\mathrm{z}$ grupa dzieci zdrowych $\mathrm{w}$ podobnym wieku. U dzieci z implantami rejestracje EACR wykonywano też po 12 i 24 miesiącach po wszczepieniu ostatniego implantu, a ich wyniki zestawiano ze sobą. Badania wykazały, że w miarę upływu czasu latencje EACR wywoływane przez bodźce prezentowane zarówno w uchu implantowanym jako pierwsze, jak i w uchu implantowanym później ulegały skróceniu. Ponadto zaobserwowano, że po 24 miesiącach zarówno amplituda, jak i latencja fali $\mathrm{P} 1$ rejestrowanej w uchu z implantem wszczepionym później były nadal znacząco różne niż w uchu zaimplantowanym jako pierwsze. Co ciekawe, po 24 miesiącach różnice 
w latencjach pomiędzy obiema zaimplantowanymi stronami zaczęły się zacierać i nie były już statystycznie istotne. Latencje EACR rejestrowane u dzieci implantowanych zaczęły zbliżać się też do normy wiekowej, chociaż amplitudy składowych wywoływanych przez bodźce podawane przez implant wszczepiony później były wciąż dłuższe niż te rejestrowane u dzieci zdrowych. Badania te pokazują, że rejestracja różnych składowych EACR (o latencji wcześniejszej i późniejszej, jak fala N2) pozwala na ocenę dojrzewania i funkcjonowania procesów słuchowych zarówno w czasie, jak i na różnych poziomach analizy informacji.

Bardzo ciekawym przykładem eksperymentu z wykorzystaniem rejestracji fali N2, którego wyniki mogą inspirować klinicystów i który znajdzie być może wkrótce zastosowanie w ocenie i diagnostyce procesów językowych, jest doświadczenie, które wykonali Schmitt i wsp. (2000) [196]. Autorzy ci, rejestrując falę N2, postanowili odpowiedzieć sobie na pytanie, która $z$ informacji (fonologiczna czy semantyczna), zawartych w przetwarzanym materiale językowym, analizowana jest jako pierwsza. Przeprowadzony eksperyment składał się z dwóch części. Część pierwsza polegała na tym, iż osobom badanym prezentowano różne obrazki, a ich zadaniem było rozpoznanie, czy na obrazku znajduje się zwierzę czy przedmiot. W zależności od podjętej decyzji należało nacisnąć prawy (zwierzę) lub lewy (przedmiot) przycisk. Równocześnie należało dokonać oceny fonologicznej prezentowanych bodźców i określić, czy nazwa pokazywanej „rzeczy” zaczyna się samogłoską czy spółgłoską. To wpływało także na udzielaną odpowiedź. Przycisk należało nacisnąć bowiem wyłącznie wtedy, gdy nazwa pokazywanej „rzeczy” rozpoczynała się spółgłoską. Część druga eksperymentu była natomiast odwróceniem pierwszej sytuacji i zależała od oceny semantycznej. Decyzja, czy nacisnąć przycisk czy też powstrzymać się od udzielania odpowiedzi, zależała bowiem w tym wypadku od tego, czy pokazywany obrazek przedstawiał zwierzę czy przedmiot. Jak widać, przeprowadzone doświadczenie było pewną (dość złożoną) formą zadania Go-Nogo. W odpowiedziach na bodźce Nogo, kiedy należało powstrzymać się od odpowiedzi ruchowych, rejestrowano oczywiście wyraźne fale N2. Analizując i porównując latencje tych fal w pierwszej i drugiej części eksperymentu, można było określić, który rodzaj procesów biorących udział w rozumieniu mowy zachodzi w czasie jako pierwszy. Wyniki badań przedstawione przez Schmitt i wsp. (2000) [196] przyniosły zaskakujące rezultaty. Okazało się bowiem, że fale N2 generowane w części „semantycznej" eksperymentu pojawiały się szybciej o około $90 \mathrm{~ms}$ niż w części fonologicznej, co świadczy o tym, że - wbrew temu, czego można było oczekiwać - informacja semantyczna zawarta w bodźcach przetwarzana jest jako pierwsza. Jak donoszą autorzy pracy, wyniki ich badań oparte na analizie fali N2 pokazują również, że pewna forma informacji zawarta w słowie pisanym dostępna jest już nawet $160 \mathrm{~ms}$ po pojawieniu się tego słowa w polu widzenia.

\section{Fala P3}

Najczęściej opisywaną w literaturze składową endogenną słuchowych potencjałów korowych, która z roku na rok wzbudza coraz większe zainteresowanie badaczy ze względu na możliwości jej klinicznego wykorzystania, jest fala P3. Jak wspomniano wcześniej, większość teorii dotyczących funkcjonalnego znaczenia tego komponentu ma jeden wspólny mianownik. Mówią one mianowicie, że fala P3 jest bioelektryczną odpowiedzią (reprezentacją) powiązaną z „jakimś” mózgowym procesem poznawczym, mającym miejsce na wyższych piętrach przetwarzania, związanym z rozpoznaniem oraz klasyfikacją bodźca akustycznego (jeżeli stymulacja była słuchowa) i/lub jego nowością. Z powyższego faktu wynika, że fala P3 stanowić może „bardzo dobre” narzędzie diagnostyczne do badania procesów poznawczych związanych $\mathrm{z}$ opracowaniem bodźców słuchowych zachodzącym na wyższym poziomie analizy informacji.

Fala P3 - kliniczne zastosowanie w neurologii, psychiatrii $i$ audiologii

W praktyce klinicznej komponent P3, a zwłaszcza jej późniejsza składowa - P3b, są więc od wielu lat wykorzystywane, podobnie jak fala N2, w badaniach i diagnostyce zaburzeń procesów poznawczych u pacjentów z problemami o charakterze głównie neurologicznym lub/i psychicznym: np. u osób z różnym stopniem demencji [197] - w tym z chorobą Alzheimera [198], u osób uzależnionych od alkoholu, pacjentów cierpiących na choroby neurodegeneracyjne [199], autyzm [200] czy schizofrenię [201] oraz wielu innych. We wszystkich tych przypadkach amplituda fali P3 z reguły ulega obniżeniu, a latencja wydłużeniu.

Kliniczne zastosowanie fali P3 w audiologii przez wiele lat sprowadzało się w zasadzie do oceny dysfunkcji procesów uwagowych współwystępujących z różnego rodzaju zaburzeniami słuchowymi. Pokazują to na przykład badania Salamat i McPherson (1999) [202], którzy falę P3 rejestrowali u osób zdrowych i z zespołem nadpobudliwości ruchowej (ang. attention deficyt hyperactivity disorder, ADHD) w trakcie w wykonywania tzw. słuchowego testu uwagi ciągłej (ang. auditory continuous performance task, ACPT). W teście tym zadaniem osób badanych było udzielenie odpowiedzi ruchowej na tony o różnej częstotliwości $(1000 \mathrm{~Hz}, 1500 \mathrm{~Hz}, 2000 \mathrm{~Hz}$ ) oraz powstrzymanie się od reakcji polegającej na naciskaniu przycisku na pojawiające się co jakiś czas tony $250 \mathrm{~Hz}$. Zmienną, którą manipulowano w trakcie badania, był odstęp pomiędzy prezentowanymi bodźcami. Salamat i McPherson (1999) [202] wykazali, że amplituda fali P3 ulega wyraźnemu obniżeniu zarówno u osób zdrowych, jak i u osób z ADHD wówczas, gdy odstęp ten ulega zmniejszeniu. Jak podkreślają autorzy, istotne obniżenie amplitudy było jednak o wiele wyraźniejsze u osób z ADHD niż u osób zdrowych. Wskazuje to co prawda na realizację procesów poznawczych związanych z falą P3 w obu badanych grupach, widać jednak, że jakość, stopień realizacji i dostępność procesów, których reprezentantem jest składowa P3, u osób z ADHD była wyraźnie mniejsza. Autorzy podkreślają również, że badania $\mathrm{z}$ wykorzystaniem fali $\mathrm{P} 3 \mathrm{w}$ populacji osób z ADHD są bardzo istotne, gdyż niewykluczone, że będą one mogły zostać wykorzystane w przyszłości do odróżniania osób z „rzeczywistym” ADHD od osób wykazujących jedynie zachowania charakterystyczne dla tego zespołu. Może to być przydatne dla planowania różnego rodzaju interwencji terapeutycznych, zwłaszcza że różnego rodzaju zaburzenia uwagi słuchowej bardzo często są obecne w populacji osób z ADHD, a leczenie i terapia osób z dysfunkcjami słuchowymi współwystępującymi 
z ADHD bądź niewspółwystępującymi z ADHD może się istotnie różnić.

Z kolei w innej publikacji McPherson i Ballachanda (2007) [3], na podstawie swoich wcześniejszych badań, opisują, że u wielu dzieci w wieku szkolnym, u których stwierdza się ADHD, ulega zmniejszeniu amplituda oraz wydłuża się latencja fali $\mathrm{P} 3 \mathrm{w}$ porównaniu ze zdrowymi rówieśnikami. Wykazano ponadto, że latencja fali P3 u dzieci z ADHD jest parametrem o wiele bardziej zmiennym niż u dzieci zdrowych. Nieprawidłowości w tym zakresie świadczą natomiast, że u dzieci z ADHD problemem jest raczej niewłaściwe przetwarzanie poznawcze informacji niż nieprawidłowa detekcja różnic w zakresie jedynie informacji słuchowej.

Badaniami pokazującymi kolejne potencjalne zastosowanie fali P3 w audiologii są eksperymenty przeprowadzone przez Hurleya i Musieka (1997) [203]. Badacze ci na podstawie zmian fali P3 oceniali efektywność testów przetwarzania słuchowego u osób $\mathrm{z}$ trwałym uszkodzeniem mózgu. Tak jak w badaniach osób z ADHD zastosowano aktywną procedurę „oddball”. Jako bodźce „standard” posłużyły tony o częstotliwości $1000 \mathrm{~Hz}$, bodźcami „dewiant” były natomiast dźwięki o częstotliwości $2000 \mathrm{~Hz}$. Wykazano, że procedura stosowana do rejestracji fali P3, wykorzystująca taki schemat stymulacji, ma trafność w wykrywaniu organicznego uszkodzenia ośrodkowego układu nerwowego na poziomie $59 \%$. Według autorów rejestracja fali P3 o parametrach będących w normie pozwalała stwierdzić z 98-proc. pewnością, że badany pacjent nie ma zaburzeń dotyczących ośrodkowej części układu słuchowego.

Fala P3 może być również wykorzystana w badaniu zmian przetwarzania słuchowego wywołanych długotrwałą deprywacją oraz do oceny tego, jak zmiany te kształtują się po zastosowaniu aparatów słuchowych. Na przykład Hutchinson i McGill (1997) [204] przeprowadzili badania na grupie dzieci w wieku 9-18 lat $\mathrm{z}$ głęboką obustronną głuchotą, które korzystały z jednego aparatu słuchowego. Dzięki zastosowaniu słuchowej wersji aktywnej procedury „oddball”, w trakcie której rejestrowano komponent P3, wykazano wyraźną asymetrię fali pomiędzy młodszymi a starszymi dziećmi korzystającymi z aparatu, jak również pomiędzy dziećmi z aparatami a dziećmi zdrowymi, które w badaniach stanowiły grupę kontrolną. Chociaż celem opisanych badań było przede wszystkim pokazanie znaczenia sztucznego wyrównywania ubytków słuchowych, wykazano również kliniczną użyteczność fali P3 w ocenie funkcji słuchowych u osób korzystających z aparatów słuchowych.

Falę P3 próbowano wykorzystać również kilkakrotnie do oceny funkcjonowania poznawczego u pacjentów korzystających z implantu ślimakowego [205-207]. Jordan i wsp. (1997) [206] wykazali na przykład, że zmiany w zakresie komponentu P3 u pacjentów z implantami są bardzo spójne $\mathrm{z}$ behawioralnym wykonaniem zadań $\mathrm{w}$ aktywnej procedurze „oddball”. Pacjenci z implantem ślimakowym, którzy identyfikowali poprawnie ruchowo bodźce „dewiant”, generowali bowiem wyraźny komponent P3. Z kolei u kilku pacjentów z implantem, których wykonanie behawioralne testu „oddball” nie było poprawne, fal P3 nie udało się zarejestrować. Z kolei Micco i wsp. (1995) [207] w swoich badaniach, wykorzystując paradygmat „oddball” oparty nie na bodźcach tonalnych, lecz na syntetycznie generowanych sylabach /da/ oraz /di/, wykazali, że u pacjentów, którym wszczepiono implant ślimakowy, amplituda i latencja fali P3 nie różniły się od tych samych parametrów składowej rejestrowanej u osób zdrowych.

Jednym z najbardziej obiecujących zastosowań procedury P3 jest jednak wykorzystanie zmian obserwowanych w parametrach fali P3 do oceny procesów przetwarzania informacji słuchowej i procesów poznawczych u osób z tzw. ośrodkowymi zaburzeniami słuchu (ang. central auditory processing disorder, CAPD). Jak pokazują ostatnie badania u osób z CAPD, nieprawidłowe funkcjonowanie poznawcze, zwłaszcza w zakresie uwagi, może stanowić główną przyczynę obserwowanych klinicznie specyficznych problemów z przetwarzaniem słuchowym [208-210]. Potwierdzają to między innymi liczne badania z wykorzystaniem fali P3, której amplituda i latencja u osób (dorosłych i dzieci) z CAPD jest z reguły odpowiednio obniżona i wydłużona [77,211].

\section{Fala N400 - składowa (potencjał) semantyczny}

Fala N400 również jest składową endogenną słuchowych potencjałów korowych, która stwarza pewne możliwości jej klinicznego zastosowania w ocenie i diagnostyce zwłaszcza procesów językowych, związanych nieodłącznie z przetwarzaniem słuchowym [53].

Fala N400 - potencjalne kliniczne zastosowanie $w$ badaniu funkcji językowych

Jednym z potencjalnych klinicznych zastosowań komponentu N400 może być na przykład wykorzystanie fali do oceny funkcji językowych u różnych grup pacjentów. Tego typu próbę podjęli na przykład Byrne i wsp. (1995) [212] w swoich badaniach, których celem było sprawdzenie poziomu słownictwa u dziecka z zaburzeniami komunikacji językowej i dysfunkcjami motorycznymi. Testom poddano dziecko z porażeniem mózgowym, którego wyniki zestawiono $\mathrm{z}$ rezultatami grupy dzieci zdrowych. Do wyzwalania fali N400 wykorzystano listę słów jednego z amerykańskich testów do oceny zasobów językowych u dzieci (ang. Peabody Volcabulary Test-Revised). W badaniu pokazywane były wizualne piktogramy słów, z którymi jednocześnie podawana była spójna lub niespójna ich reprezentacja słuchowa. Słowa użyte w badaniu dostosowane były do różnych poziomów rozwoju (pochodziły ze słownika dla dzieci w wieku przedszkolnym, szkolnym oraz dla osób dorosłych). Po zakończeniu badań okazało się, że zarówno dziecko z porażeniem, jak i badane dzieci zdrowe poprawnie rozpoznawały wszystkie słowa $\mathrm{z}$ listy zarówno dla przedszkolaków, jak i dzieci szkolnych. W przypadku wszystkich słów zawartych w tych słownikach zaobserwowano bowiem efekt dotyczący amplitudy fali N400. Polegał on na tym, że słowa, których piktogramy były niespójne z ich słuchową reprezentacją, generowały składową N400 o wyraźnie większej amplitudzie. Natomiast, gdy reprezentacje wzrokowa i słuchowa słów zgadzały się, fala N400 nie występowała w ogóle lub miała znacznie obniżoną amplitudę. Efektu tego typu nie zaobserwowano natomiast $\mathrm{w}$ przypadku słów $\mathrm{z}$ listy dla osób dorosłych, co świadczyło, że zarówno dziecko z porażeniem, jak i dzieci zdrowe nie znały znaczenia prezentowanych słów. Byrne 
i wsp. (1999) [213], chcąc sprawdzić kliniczną przydatność testu N400, przeprowadzili kolejne badania na znacznie większej (56-osobowej) grupie dzieci zdrowych w różnym wieku. Badania te potwierdziły obserwacje poczynione w pierwszym eksperymencie, a konkluzją z badań było między innym zaproponowanie konkretnego protokołu (obiektywnego testu) do oceny funkcji językowych z wykorzystaniem komponentu N400 zarówno u osób zdrowych, jak i cierpiących na różne dysfunkcje.

Komponent N400 usiłowano z powodzeniem wykorzystać także w kilku badaniach do wykrycia i ilościowego pomiaru zaburzeń percepcji mowy u pacjentów z różnego stopnia afazją Wernickego. W badaniach tych rejestrację fali N400 wykonywaną u pacjentów porównywano $\mathrm{z}$ identycznym testem elektrofizjologicznym przeprowadzanym u osób zdrowych będących $\mathrm{w}$ podobnym wie$\mathrm{ku}$. We wszystkich badaniach u pacjentów $\mathrm{z}$ afazją obserwowano redukcję amplitudy oraz wydłużenie latencji fali N400 w porównaniu z grupą osób zdrowych [214,215].

Badania z wykorzystaniem fali N400 do oceny przetwarzania semantycznego i gramatycznego u dzieci w wieku szkolnym już od dość dawna prowadzili także Kutas i Hillyard (1983) [216]. Wykazano w nich między innymi, że dzieci z większymi problemami językowymi charakteryzują się mniejszą odpowiedzią N400. Potwierdzono w nich również, że fala N400 generowana jest przez zdania zawierające niezgodność semantyczną, a nie zdania zawierające błędy gramatyczne.

Komponent N400 rejestrowano i próbowano z powodzeniem oceniać równocześnie $\mathrm{z}$ inną składową endogenną słuchowych potencjałów korowych - falą N2. Connolly i wsp. (1992) [55], wykorzystując procedurę fonologicznego maskowania zdań służących do wywoływania odpowiedzi korowych, dokonanego za pomocą tzw. babble talk (nałożona na siebie mowa kilku osób), wykazali, że przy dokładnym maskowaniu fala N400 ulega zmniejszeniu, tymczasem komponent N2 nie podlega tego typu zmianom. Efekt ten po raz kolejny wskazuje, że fala N400 związana jest $z$ przetwarzaniem językowym, natomiast potencjał N2 wyłącznie ze słuchowym przetwarzaniem prezentowanych zdań. Rejestrując oba potencjały w trakcie jednego badania, można obiektywnie oceniać jednocześnie oba aspekty przetwarzania i szacować, na jakim poziomie analizy informacji werbalnej występuje problem.

Fala N400 być może znajdzie zastosowanie również w diagnozie dysleksji. Przesłanki ku temu stwarzają chociażby wyniki badań Cocha i Holcomba (2003) [78], którzy porównywali grupę dzieci zdrowych i grupę dzieci z dysleksją rozwojową, u których na podstawie testów behawioralnych stwierdzono trudności w rozpoznawaniu znaczenia słów. Zastosowano test elektofizologiczny, w którym oceniane były zarówno amplituda, jak i latencja fali N400 wywoływanej przez słowa o różnym stopniu trudności znaczeniowej. Wykazano, że o ile u dzieci zdrowych rejestrowano wyraźną falę N400, o tyle u dzieci z trudnościami w czytaniu wyraźnie zaznaczona fala N400 nie występowała. Jak wskazują autorzy, analiza obecności tego efektu może stanowić narzędzie pomocne we wstępnej diagnozie i obiektywnej ocenie problemów z przetwarzaniem językowym już na wczesnym etapie rozwoju tych procesów.
Wady i zalety procedur opartych na rejestracji związanych ze zdarzeniem (endogennych) słuchowych potencjałów korowych

Przedstawione w pracy przykłady badań pokazują, że procedury badawcze i diagnostyczne oparte na rejestracji składowych endogennych CAEP (fal N2, P3, N400) mogą stwarzać dość spore możliwości w zakresie poznania samych mechanizmów i procesów poznawczych czy językowych - nieodłącznie związanych z przetwarzaniem słuchowym, jak również jako narzędzia kliniczne być wykorzystywane do diagnostyki różnych grup pacjentów $\mathrm{z}$ zaburzeniami tych funkcji. Mówiąc o testach opartych na każdej z opisywanych fal, trzeba pamiętać jednak o pewnych ograniczeniach tych metod, zwłaszcza w odniesieniu do diagnostyki indywidualnej. Jednym $\mathrm{z}$ nich jest, podobnie jak w przypadku fali MMN, duża zmienność komponentów, zarówno jeżeli chodzi o amplitudę, jak i latencję fal, pod wpływem wielu czynników egzo- i endogennych (przegląd patrz np. [24,38]). Powoduje to, iż niekiedy trudno jest wyznaczyć standardy wykonania badania. Czynnikiem, który znacząco utrudnia kliniczne zastosowanie metod opartych na endogennych składowych CAEP, jest również duża zmienność osobnicza odpowiedzi. Warto także wspomnieć, że pojawienie się poszczególnych fal w korowej odpowiedzi wywołanej nie zawsze idzie w parze $\mathrm{z}$ behawioralną odpowiedzią i często zdarza się, że u osoby badanej rejestruje się bardzo wyraźną odpowiedź bioelektryczną, tymczasem nie udziela ona żadnej odpowiedzi behawioralnej. Powoduje to, że trudno jest opracować i wyznaczyć wartości normatywne parametrów poszczególnych składowych. Problem stwarza też interpretacja wyników badania. Jak wspomniano wcześniej, w przypadku fali N2 stosunkowo ograniczona liczba dostępnych badań dotyczących wyłącznie tej składowej powoduje, iż nadal trudno jest mówić o dokładnym poznaniu funkcjonalnego znaczenia tego komponentu. Podobnego argumentów można użyć, mówiąc o falach P3 czy N400. Badań dotyczących tych składowych jest co prawda znacząco więcej, jednak funkcjonalne znaczenie obu fal jest wciąż nie do końca poznane. W przypadku nieprawidłowego wyniku badania dokładne określenie, jaki proces lub kilka procesów opracowania bodźca zostało zaburzonych może być więc trudne i nieprecyzyjne. Nieprawidłowe wartości parametrów opisujących fale mogą więc jedynie dostarczyć ogólnych informacji wskazujących, że mamy do czynienia z problemem przetwarzania informacji najprawdopodobniej natury poznawczej czy językowej, a nie konkretnych i specyficznych diagnostycznych wskazówek, gdzie dokładnie tkwi problem. Dużym utrudnieniem podczas oceny klinicznej składowych endogennych CAEP może być również konieczność aktywnego zaangażowania się osoby badanej w zadania służące do wyzwalania składowych. Wykorzystanie poszczególnych komponentów do oceny procesów językowych czy poznawczych związanych z przetwarzaniem bodźców słuchowych jest więc tak naprawdę ograniczone wyłącznie do populacji zmotywowanych i współpracujących pacjentów. W wielu przypadkach o wiele łatwiej i korzystniej jest posłużyć się testami behawioralnymi [1]. Wykonując testy elektrofizjologiczne oparte na endogennych składowych CAEP związanych ze zdarzeniem i planując wykorzystanie tych metod jako narzędzia użytecznego klinicznie, warto zatem pamiętać o wszystkich powyższych ograniczeniach i niedogodnościach. 


\section{Podsumowanie}

Słuchowe potencjały korowe (CAEP) to jedna $\mathrm{z}$ metod elektrofizjologicznych, umożliwiająca obiektywną ocenę funkcjonowania procesów i ośrodków mózgowych związanych z przetwarzaniem bodźców słuchowych na wyższym poziomie. Pomimo że metoda ta posiada pewne wady i wciąż nie stanowi głównego nurtu w rutynowych testach diagnostycznych, wiele przedstawionych w pracy badań eksperymentalnych oraz prób wykorzystania klinicznego pokazuje, że badania i testy diagnostyczne oparte na CAEP stwarzają olbrzymie możliwości aplikacyjne przede wszystkim $\mathrm{w}$ audiologii, ale również $\mathrm{w}$ innych dziedzinach nauki (np. neurologii, psychiatrii, psychologii i innych) zajmujących się funkcjonowaniem ośrodkowego układu nerwowego.

Artykut powstat $w$ zwiazku z realizacja projektu „Zintegrowany system narzędzi do diagnostyki i telerehabilitacji schorzeń narzadów zmysłów (słuchu, wzroku, mowy, równowagi, smaku, powonienia)" wspólfinansowanego przez Narodowe Centrum Badań i Rozwoju w ramach Programu STRATEGMED.

\section{Piśmiennictwo:}

1. Stapells DR. Cortical event-related potentials to auditory stimuli. W: Katz J, red. Handbook of clinical audiology. $5^{\text {th }}$ ed., Philadelphia: Lippincott Williams \& Wilkins; 2002, s. 378-406.

2. Martin BA, Tremblay KL, Stapells DR. Principles and applications of cortical auditory evoked potentials. W: Burkard RF, Don M, Eggermont JJ, red. Auditory evoked potentials: basic principles and clinical application. Philadelphia: Lippincott Williams \& Wilkins; 2007, s. 482-507.

3. McPherson DL, Ballachanda BB. Middle and long latency auditory evoked potentials. W: Roester RJ, Valente M, Hosford-Dunn H, red. Audiology: diagnosis. New York: Thieme; 2007, s. $443-78$.

4. Knight RT, Scabini D, Woods DL, Clayworth C. The effects of lesions of superior temporal gyrus and inferior parietal lobe on temporal and vertex components of the human AEP. Electroencephalogr Clin Neurophysiol, 1988; 70(6): 499-509.

5. Squires NK, Squires KC, Hillyard SA. Two varieties of long-latency positive waves evoked by unpredictable auditory stimuli in man. Electroencephalogr Clin Neurophysiol, 1975; 38(4): 387-401.

6. Luck SJ. An introduction to the event-related potential technique. Cambridge Massachusetts: The MIT Press; 2005.

7. Jaśkowski P. Zarys psychofizjologii. Warszawa: Wyższa Szkoła Finansów i Zarządzania; 2004.

8. Näätänen R, Picton T. The N1 wave of the human electric and magnetic response to sound: a review and an analysis of the component structure. Psychophysiology, 1987; 24(4): 375-425.

9. Crowley KE, Colrain IM. A review of the evidence for P2 being an independent component process: age, sleep and modality. Clin Neurophysiol Off J Int Fed Clin Neurophysiol, 2004 115(4): 732-44.

10. Scherg M, Vajsar J, Picton T. A source analysis of the late human auditory evoked potentials. J Cogn Neurosci, 1989; 1(4) $336-55$.

11. Rif J, Hari R, Hämäläinen MS, Sams M. Auditory attention affects two different areas in the human supratemporal cortex. Electroencephalogr Clin Neurophysiol, 1991; 79(6): 464-72.

12. Oades RD, Dittmann-Balcar A, Zerbin D. Development and topography of auditory event-related potentials (ERPs): mismatch and processing negativity in individuals 8-22 years of age. Psychophysiology, 1997; 34(6): 677-93.

13. Ponton CW, Eggermont JJ, Kwong B, Don M. Maturation of human central auditory system activity: evidence from multi-channel evoked potentials. Clin Neurophysiol, 2000; 111(2): 220-36

14. Vaughan HG, Ritter W, Simson R. Topographic analysis of auditory event-related potentials. Prog Brain Res, 1980; 54: $279-85$
15. Hari R, Aittoniemi K, Järvinen M-L, Katila T, Varpula T. Auditory evoked transient and sustained magnetic fields of the human brain localization of neural generators. Exp Brain Res, 1980; 40(2): 237-40.

16. Scherg M, Cramon D Von. Two bilateral sources of the late AEP as identified by a spatio-temporal dipole model. Electroencephalogr Clin Neurophysiol Potentials Sect, 1985; 62(1): 32-44.

17. Wood CC, Wolpaw JR. Scalp distribution of human auditory evoked potentials II Evidence for overlapping sources and involvement of auditory cortex. Electroencephalogr Clin Neurophysiol, 1982; 54(1): 25-38.

18. Grillon C, Ameli R. Methods of affective clinical psychophysiology. W: Charney DS, Nestler EJ, red. Neurobiology of Mental Illness. New York: Oxford University Press; 2004, s. 127-41.

19. Martin BA, Kurtzberg D, Stapells DR. The effects of decreased audibility produced by high-pass noise masking on N1 and the mismatch negativity to speech sounds/ba/and/da. J Speech Lang Hear Res, 1999; 42(2): 271-86.

20. Arkadiusz Rojczyk. Parametr VOT w języku polskim i angielskim. Badanie Percepcji LingVaria IV 1, 2009: 29-47.

21. Tremblay KL, Shahin AJ, Picton T, Ross B. Auditory training alters the physiological detection of stimulus-specific cues in humans. Clin Neurophysiol, 2009; 120(1): 128-35.

22. Voice-onset time. Wikipedia Free Encycl, 2014. https://en.wikipedia.org/wiki/Voice-onset_time

23. Luck SJ, Kappenman ES. The Oxford Handbook of Event-Related Potential Components. Oxford University Press; 2012.

24. Milner R. Słuchowe potencjały korowe. Czesść II. Teoretyczne podstawy generacji oraz charakterystyka wybranych komponentów. Nowa Audiofonologia, 2015; 4(2): 28-42.

25. Milner R. Słuchowe potencjały korowe. Część I. Klasyfikacja oraz wybrane techniczne aspekty rejestracji odpowiedzi. Nowa Audiofonologia, 2015; 4(2): 17-27.

26. Näätänen R, Paavilainen P, Rinne T, Alho K. The mismatch negativity (MMN) in basic research of central auditory processing: A review. Clin Neurophysiol, 2007; 118(12): 2544-90.

27. Picton TW: Auditory evoked potentials. W: Daly DD, Pedley TA, red. $2^{\text {nd }}$ ed. Current Practice of Clinical Electroencephalography. New York: Raven Press; 1990, s. 625-78.

28. Alho K. Cerebral generators of mismatch negativity (MMN) and its magnetic counterpart (MMNm) elicited by sound changes. Ear Hear, 1995; 16(1): 38-51.

29. Näätänen R, Paavilainen $P$, Alho K, Reinikainen K, Sams M. The mismatch negativity to intensity changes in an auditory stimulus sequence. Electroencephalogr Clin Neurophysiol Suppl, 1987; 40: 125-31. 
30. Joutsiniemi S-L, Ilvonen T, Sinkkonen J, Huotilainen M, Tervaniemi M, Lehtokoski A i wsp. The mismatch negativity for duration decrement of auditory stimuli in healthy subjects. Electroencephalogr Clin Neurophysiol Potentials Sect, 1998; 108(2): 154-59.

31. Näätänen R, Jiang D, Lavikainen J, Reinikainen K, Paavilainen P. Event-related potentials reveal a memory trace for temporal features. NeuroReport, 1993; 5(3): 310-12.

32. Näätänen R, Alho K. Mismatch negativity - the measure for central sound representation accuracy. Audiol Neurootol, 1997; 2(5): 341-53.

33. Folstein JR, Petten C Van. Influence of cognitive control and mismatch on the N2 component of the ERP: a review. Psychophysiology, 2008; 45(1): 152-70.

34. Patel SH, Azzam PN. Characterization of N200 and P300: selected studies of the event-related potential. Int J Med Sci, 2005; 2(4): 147-54.

35. Näätänen R, Gaillard AWK. The orienting reflex and the N2 deflection of the event-related potential (ERP). Adv Psychol, 1983; 10: 119-41.

36. Sutton S, Braren M, Zubin J, John ER. Evoked-potential correlates of stimulus uncertainty. Science, 1965; 150(3700): 1187-88.

37. Kok A. On the utility of $\mathrm{P} 3$ amplitude as a measure of processing capacity. Psychophysiology, 2001; 38(3): 557-77.

38. Polich J, Kok A. Cognitive and biological determinants of P300: an integrative review. Biol Psychol, 1995; 41(2): 103-46.

39. Kida T, Nishihira Y, Hatta A, Wasaka T, Tazoe T, Sakajiri Y i wsp. Resource allocation and somatosensory P300 amplitude during dual task: effects of tracking speed and predictability of tracking direction. Clin Neurophysiol, 2004; 115(11): 2616-28.

40. Polich J. Theoretical overview of P3a and P3b. W: Polich J, red. Detection of change. Springer; 2003, s. 83-98.

41. Buchwald JS. Animal models of cognitive event-related potentials. W: Event-related potentials of the brain. New York: Oxford University Press; 1990, s. 57-75.

42. Buchwald JS. Comparison of plasticity in sensory and cognitive processing systems. Clin Perinatol, 1990; 17(1): 57-66.

43. Donchin E. Presidential address, 1980 Surprise! Surprise? Psychophysiology, 1981; 18(5): 493-513.

44. Donchin E, Coles MGH. Is the P300 component a manifestation of context updating? Behav Brain Sci, 1988; 11(03): 357-74.

45. Verleger R. Event-related potentials and cognition: A critique of the context updating hypothesis and an alternative interpretation of P3. Behav Brain Sci, 1988; 11(3): 343-56.

46. Polich J. Updating P300: an integrative theory of P3a and P3b. Clin Neurophysiol Off J Int Fed Clin Neurophysiol, 2007; 118(10): 2128-48

47. Verleger R. On the utility of P3 latency as an index of mental chronometry. Psychophysiology, 1997; 34(2): 131-56.

48. Kutas M, Federmeier KD. Thirty years and counting: Finding meaning in the N400 component of the event-related brain potential (ERP). Annu Rev Psychol, 2011; 62(1): 621-47.

49. Näätänen R. Attention and brain function. Psychology Press; 1992.

50. Picton TW. The P300 wave of the human event-related potential. J Clin Neurophysiol, 1992; 9(4): 456-79.

51. Verleger R, Jaśkowski P, Wascher E. Evidence for an integrative role of $\mathrm{P} 3 \mathrm{~b}$ in linking reaction to perception. J Psychophysiol, 2005; 19(3): 165-81.
52. Coles MG, Smid HG, Scheffers MK, Otten LJ. Mental chronometry and the study of human information processing. W: Rugg MD, Coles MGH, red. Electrophysiology of mind: event-related brain potentials and cognition. New York: Oxford University Press, 1995; s. 86-131.

53. Senderski A. Potencjały związane ze zdarzeniem (ERP) - obiektywne narzędzie do oceny procesu rozumienia mowy. Audiofonologia, 2005; 27: 11-8.

54. Kutas M, Hillyard SA. Brain potentials during reading reflect word expectancy and semantic association. Nature, 1984; 307: 161-63.

55. Connolly JF, Phillips NA, Stewart SH, Brake WG. Event-related potential sensitivity to acoustic and semantic properties of terminal words in sentences. Brain Lang, 1992; 43(1): 1-18.

56. Haan H, Streb J, Bien S, Rösler F. Individual cortical current density reconstructions of the semantic N400 effect: using a generalized minimum norm model with different constraints (L1 and L2 norm). Hum Brain Mapp, 2000; 11(3): 178-92.

57. Kutas M, Hillyard SA. Reading senseless sentences: Brain potentials reflect semantic incongruity. Science, 1980; 207(4427): 203-5.

58. McPherson DL. Long latency auditory evoked potentials. W: McPherson DL, red. Late potentials of the auditory system. New York: Singular Publishing Group; 1996; s. 7-21.

59. Rugg MD. Event-related potentials and the phonological processing of words and non-words. Neuropsychologia, 1984; 22(4): 435-43.

60. Radeau M, Besson M, Fonteneau E, Castro SL. Semantic, repetition and rime priming between spoken words: behavioral and electrophysiological evidence. Biol Psychol, 1998; 48(2): 183-204.

61. Kim M, Kim J, Kwon JS. The effect of immediate and delayed word repetition on event-related potential in a continuous recognition task. Brain Res Cogn Brain Res, 2001; 11(3): 387-96.

62. Hahne A, Friederici AD. Differential task effects on semantic and syntactic processes as revealed by ERPs. Cogn Brain Res, 2002; 13(3): 339-56.

63. McCarthy G, Nobre AC. Modulation of semantic processing by spatial selective attention. Electroencephalogr Clin Neurophysiol, 1993; 88(3): 210-19.

64. Cone-Wesson B, Wunderlich J. Auditory evoked potentials from the cortex: audiology applications. Curr Opin Otolaryngol Head Neck Surg, 2003; 11(5): 372-77.

65. Hamburger HL, Triantafyllou NI. Clinical applications of auditory event related potentials in neurology. Brain Topogr, 1990; 3(1): 49-52.

66. Pfefferbaum A, Wenegrat BG, Ford JM, Roth WT, Kopell BS. Clinical application of the P3 component of event-related potentials II Dementia, depression and schizophrenia. Electroencephalogr Clin Neurophysiol Potentials Sect, 1984; 59(2): 104-24.

67. Wang J, Miyazato H, Randall M, Hokama H, Hiramatsu K-I, Ogura C. The N200 abnormalities of auditory event-related potentials in patients with panic disorder. Prog Neuropsychopharmacol Biol Psychiatry, 2003; 27(6): 1013-21.

68. Tomé D, Sampaio M, Mendes-Ribeiro J, Barbosa F, Marques-Teixeira J. Auditory event-related potentials in children with benign epilepsy with centro-temporal spikes. Epilepsy Res, 2014; 108(10): 1945-49.

69. Lew HL, Gray M, Poole JH. Simultaneous measurement of perceptual and motor cortical potentials: implications for assessing information processing in traumatic brain injury. Am J Phys Med Rehabil Assoc Acad Physiatr, 2009; 88(1): 1-6. 
70. Risetti M, Formisano R, Toppi J, Quitadamo LR, Bianchi L, Astolfi L i wsp. On ERPs detection in disorders of consciousness rehabilitation. Front Hum Neurosci, 2013; 7: 775.

71. Hernández OH, García-Martínez R, Monteón V. Alcohol effects on the P2 component of auditory evoked potentials. An Acad Bras Ciênc, 2014; 86(1): 437-49.

72. Howe AS, Bani-Fatemi A, Luca V De. The clinical utility of the auditory P300 latency subcomponent event-related potential in preclinical diagnosis of patients with mild cognitive impairment and Alzheimer's disease. Brain Cogn, 2014; 86: 64-74.

73. Vecchio F, Määttä S. The Use of Auditory Event-Related Potentials in Alzheimer's Disease Diagnosis. Int J Alzheimer's Dis, 2011: e653173.

74. Martin BA, Boothroyd A. Cortical, auditory, event-related potentials in response to periodic and aperiodic stimuli with the same spectral envelope. Ear Hear, 1999; 20(1): 33-44.

75. Whiting KA, Martin BA, Stapells DR. The effects of broadband noise masking on cortical event-related potentials to speech sounds /ba/ and /da/. Ear Hear, 1998; 19(3): 218-31.

76. Jirsa RE, Clontz KB. Long latency auditory event-related potentials from children with auditory processing disorders. Ear Hear, 1990; 11(3): 222-32.

77. Goodin DS. Clinical utility of long latency „cognitive” event-related potentials (P3): the pros. Electroencephalogr Clin Neurophysiol, 1990; 76(1): 2-5; discussion 1.

78. Coch D, Holcomb PJ. The N400 in beginning readers. Dev Psychobiol, 2003; 43(2): 146-66.

79. Appleby SV, McDermick P, Scott JW. The sound evoked cerebral response as a test of hearing. Electroencephalogr Clin Neurophysiol, 1963; 15: 370-75.

80. Cone B, Whitaker R. Dynamics of infant cortical auditory evoked potentials (CAEPs) for tone and speech tokens. Int J Pediatr Otorhinolaryngol, 2013; 77(7): 1162-73.

81. Rose DE, Keating LW, Hedgecock LD, Miller KE, Schreurs KK. A comparison of evoked response audiometry and routine clinical audiometry. Audiol Off Organ Int Soc Audiol, 1972; 11(3): 238-43.

82. Rapin I. Evoked responses to clicks in a group of children with communication disorders. Ann N Y Acad Sci, 1964; 112 182-203.

83. Prevec TS, Cernelc S, Ribaric K. Evoked cerebral potential audiometry and hearing threshold. Audiol Off Organ Int Soc Audiol, 1976; 15(1): 39-49.

84. Rapin I, Schimmel H, Cohen MM. Reliability in detecting the auditory evoked response (AER) for audiometry in sleeping subjects. Electroencephalogr Clin Neurophysiol, 1972; 32(5): $521-28$.

85. Kraus N, McGee T, Carrell TD, Sharma A. Neurophysiologic bases of speech discrimination. Ear Hear, 1995; 16(1): 19-37.

86. Martin BA. Can the acoustic change complex be recorded in an individual with a cochlear implant? Separating neural responses from cochlear implant artifact. J Am Acad Audiol, 2007; 18(2): 126-40.

87. Formant. Wikipedia Free Encycl, 2015, https://en.wikipedia. org/wiki/Formant.

88. Reite M, Teale P, Zimmerman J, Davis K, Whalen J. Source location of a $50 \mathrm{msec}$ latency auditory evoked field component. Electroencephalogr Clin Neurophysiol, 1988; 70(6): 490-8.

89. Vasama JP, Mäkelä JP, Parkkonen L, Hari R. Auditory cortical responses in humans with congenital unilateral conductive hearing loss. Hear Res, 1994; 78(1): 91-97.
90. Tecchio F, Bicciolo G, Campora E De, Pasqualetti P, Pizzella $\mathrm{V}$, Indovina I i wsp. Tonotopic cortical changes following stapes substitution in otosclerotic patients: a magnetoencephalographic study. Hum Brain Mapp, 2000; 10(1): 28-38.

91. Ceponiene R, Haapanen M-L, Ranta R, Näätänen R, Hukki J. Auditory sensory impairment in children with oral clefts as indexed by auditory event-related potentials. J Craniofac Surg, 2002; 13(4): 554-66; discussion 567.

92. Vasama JP, Mäkelä JP, Pyykkö I, Hari R. Abrupt unilateral deafness modifies function of human auditory pathways. Neuroreport, 1995; 6(7): 961-64.

93. Ponton CW, Don M, Eggermont JJ, Waring MD, Masuda A. Maturation of human cortical auditory function: differences between normal-hearing children and children with cochlear implants. Ear Hear, 1996; 17(5): 430-37.

94. Korczak PA, Kurtzberg D, Stapells DR. Effects of sensorineural hearing loss and personal hearing aids on cortical event-related potential and behavioral measures of speech-sound processing. Ear Hear, 2005; 26(2): 165-85.

95. Tremblay KL, Billings CJ, Friesen LM, Souza PE. Neural representation of amplified speech sounds. Ear Hear, 2006; 27(2): 93-103.

96. Rapin I, Graziani LJ. Auditory-evoked responses in normal, brain-damaged, and deaf infants. Neurology, 1967; 17(9): 881-94.

97. Stapells DR, Kurtzberg D. Evoked potential assessment of auditory system integrity in infants. Clin Perinatol, 1991; 18(3): 497-518.

98. Billings CJ, Bennett KO, Molis MR, Leek MR. Cortical encoding of signals in noise: effects of stimulus type and recording paradigm. Ear Hear, 2011; 32(1): 53-60.

99. Ponton CW, Don M, Waring MD, Eggermont JJ, Masuda A. Spatio-temporal source modeling of evoked potentials to acoustic and cochlear implant stimulation. Electroencephalogr Clin Neurophysiol Potentials Sect, 1993; 88(6): 478-93.

100. Firszt JB, Chambers RD, Kraus N. Neurophysiology of cochlear implant users II: comparison among speech perception, dynamic range, and physiological measures. Ear Hear, 2002; 23(6): 516-31.

101. Groenen PAP, Makhdoum M, Brink JL Van Den, Stollman MHP, Snik AFM, Broek P Van Den. The relation between electric auditory brain stem and cognitive responses and speech perception in cochlear implant users. Acta Otolaryngol (Stockh), 1996; 116(2): 785-90.

102. Maurer J, Collet L, Pelster H, Truy E, Gallégo S. Auditory late cortical response and speech recognition in digisonic cochlear implant users. The Laryngoscope, 2002; 112(12): 2220-4.

103. Friesen LM, Tremblay KL. Acoustic change complexes recorded in adult cochlear implant listeners. Ear Hear, 2006; 27(6): 678-85.

104. Eilers RE, Cobo-Lewis AB, Vergara KC, Oller DK. Longitudinal speech perception performance of young children with cochlear implants and tactile aids plus hearing aids. Scand $\mathrm{Au}$ diol Suppl, 1997; 47: 50-54.

105. Ponton C, Eggermont J, Don M, Waring M, Kwong B, Cunningham J i wsp. Maturation of the mismatch negativity: effects of profound deafness and cochlear implant use. Audiol Neurootol, 2000; 5(3-4): 167-85.

106. Sharma A, Martin K, Roland P, Bauer P, Sweeney MH, Gilley $\mathrm{P}$ i wsp. P1 latency as a biomarker for central auditory development in children with hearing impairment. J Am Acad Audiol, 2005; 16(8): 564-73.

107. Hyde M. The N1 response and its applications. Audiol Neurotol, 1997; 2(5): 281-307. 
108. Tremblay K, Kraus N, McGee T, Ponton C, Otis B. Central auditory plasticity: changes in the N1-P2 complex after speech-sound training. Ear Hear, 2001; 22(2): 79-90.

109. Atienza M, Cantero JL, Dominguez-Marin E. The time course of neural changes underlying auditory perceptual learning. Learn Mem, 2002; 9(3): 138-50.

110. Tremblay K, Kraus N, McGee T. The time course of auditory perceptual learning: neurophysiological changes during speech-sound training. Neuroreport, 1998; 9(16): 3557-60.

111. Desjardins RN, Trainor LJ, Hevenor SJ, Polak CP. Using mismatch negativity to measure auditory temporal resolution thresholds. Neuroreport, 1999; 10(10): 2079-82.

112. Rupp A, Gutschalk A, Hack S, Scherg M. Temporal resolution of the human primary auditory cortex in gap detection. Neuroreport, 2002; 13(17): 2203-7.

113. Uther M, Jansen DHJ, Huotilainen M, Ilmoniemi RJ, Näätänen R. Mismatch negativity indexes auditory temporal resolution: evidence from event-related potential (ERP) and event-related field (ERF) recordings. Cogn Brain Res, 2003; 17(3): 685-91.

114. Ungan P, Erar H, Oztürk N, Ozmen B. Human long-latency potentials evoked by monaural interruptions of a binaural click train: connection to sound lateralization based on interaural intensity differences. Audiol Off Organ Int Soc Audiol, 1992; 31(6): 318-33.

115. Wedel H von, Wedel UC von, Streppel M. Monaural and binaural time resolution ability in the aged A psychoacoustic and electrophysiological study. Acta Oto-Laryngol Suppl, 1990; 476: 161-66.

116. Bekhterev NN, Vaitulevich SF, Nikitin NI, Shestopalova LB. Comparison of binaural release from forward masking in animals and humans Electrophysiological studies. Neurosci Behav Physiol, 2002; 32(1): 71-79.

117. Fishman YI, Reser DH, Arezzo JC, Steinschneider M. Neural correlates of auditory stream segregation in primary auditory cortex of the awake monkey. Hear Res, 2001; 151(1): 167-87.

118. Kraus N, Bradlow AR, Cheatham MA, Cunningham J, King $\mathrm{CD}$, Koch DB i wsp. Consequences of neural asynchrony: A case of auditory neuropathy. J Assoc Res Otolaryngol, 2000; 1(1): 33-45.

119. Hayes EA, Warrier CM, Nicol TG, Zecker SG, Kraus N. Neural plasticity following auditory training in children with learning problems. Clin Neurophysiol, 2003; 114(4): 673-84.

120. Warrier C, Johnson K, Hayes E, Nicol T, Kraus N. Learning impaired children exhibit timing deficits and training-related improvements in auditory cortical responses to speech in noise. Exp Brain Res, 2004; 157(4): 431-41.

121. Reinke KS, He Y, Wang C, Alain C. Perceptual learning modulates sensory evoked response during vowel segregation. Cogn Brain Res, 2003; 17(3): 781-91.

122. Trainor LJ, Shahin A, Roberts LE. Effects of musical training on the auditory cortex in children. Ann N Y Acad Sci, 2003; 999(1): 506-13.

123. Näätänen R. Mismatch negativity $(\mathrm{MMN})$ : perspectives for application. Int J Psychophysiol, 2000; 37(1): 3-10.

124. Yago E, Corral MJ, Escera C. Activation of brain mechanisms of attention switching as a function of auditory frequency change. Neuroreport, 2001; 12(18): 4093-97.

125. Yago E, Escera C, Alho K, Giard M-H. Cerebral mechanisms underlying orienting of attention towards auditory frequency changes. Neuroreport, 2001; 12(11): 2583-87.

126. Sambeth A, Huotilainen M, Kushnerenko E, Fellman V, Pihko E. Newborns discriminate novel from harmonic sounds: A study using magnetoencephalography. Clin Neurophysiol, 2006; 117(3): 496-503.
127. Näätänen R, Gaillard AW, Mäntysalo S. Early selective-attention effect on evoked potential reinterpreted. Acta Psychol (Amst), 1978; 42(4): 313-29.

128. Kisley MA, Noecker TL, Guinther PM. Comparison of sensory gating to mismatch negativity and self-reported perceptual phenomena in healthy adults. Psychophysiology, 2004; 41(4): 604-12.

129. Novitski N, Tervaniemi M, Huotilainen M, Näätänen R. Frequency discrimination at different frequency levels as indexed by electrophysiological and behavioral measures. Cogn Brain Res, 2004; 20(1): 26-36.

130. Sonnadara RR, Alain C, Trainor LJ. Effects of spatial separation and stimulus probability on the event-related potentials elicited by occasional changes in sound location. Brain Res, 2006; 1071(1): 175-85.

131. Sonnadara RR, Alain C, Trainor LJ. Occasional changes in sound location enhance middle latency evoked responses. Brain Res, 2006; 1076(1): 187-92.

132. Todd J, Michie PT. Do perceived loudness cues contribute to duration mismatch negativity (MMN)? Neuroreport, 2000; 11(17): 3771-74.

133. Lyytinen H, Blomberg AP, Näätänen R. Event-related potentials and autonomic responses to a change in unattended auditory stimuli. Psychophysiology, 1992; 29(5): 523-34.

134. Sable JJ, Gratton G, Fabiani M. Sound presentation rate is represented logarithmically in human cortex. Eur J Neurosci, 2003; 17(11): 2492-96.

135. Kujala T, Karma K, Ceponiene R, Belitz S, Turkkila P, Tervaniemi $\mathrm{M}$ i wsp. Plastic neural changes and reading improvement caused by audiovisual training in reading-impaired children. Proc Natl Acad Sci, 2001; 98(18): 10509-14.

136. Shestakova A, Brattico E, Huotilainen M, Galunov V, Soloviev A, Sams M i wsp. Abstract phoneme representations in the left temporal cortex: magnetic mismatch negativity study. Neuroreport, 2002; 13(14): 1813-16.

137. Dehaene-Lambertz G, Baillet S. A phonological representation in the infant brain. NeuroReport, 1998; 9(8): 1885-88.

138. Vuust P, Pallesen KJ, Bailey C, Zuijen TL van, Gjedde A, Roepstorff A i wsp. To musicians, the message is in the meter: Pre-attentive neuronal responses to incongruent rhythm are left-lateralized in musicians. NeuroImage, 2005; 24(2): 560-64.

139. Shtyrov Y, Pulvermüller F, Näätänen R, Ilmoniemi RJ. Grammar processing outside the focus of attention: an MEG study. J Cogn Neurosci, 2003; 15(8): 1195-206.

140. Lang H, Nyrke T, Ek M, Aaltonen O, Raimo I, Näätänen R. Pitch discrimination performance and auditory event-related potentials. W: Brunia CHM, Gaillard AWK, Kok A, Mulder G, Verbaten MM, red. Psychophysiological brain research. Tilburg: Tilburg University Press; 1990, s. 294-98.

141. Mäntysalo S, Näätänen R. The duration of a neuronal trace of an auditory stimulus as indicated by event-related potentials. Biol Psychol, 1987; 24(3): 183-95.

142. Böttcher-Gandor C, Ullsperger P. Mismatch negativity in event-related potentials to auditory stimuli as a function of varying interstimulus interval. Psychophysiology, 1992; 29(5): 546-50.

143. Sams M, Hari R, Rif J, Knuutila J. The human auditory sensory memory trace persists about $10 \mathrm{sec}$ : neuromagnetic evidence. J Cogn Neurosci, 1993; 5(3): 363-70.

144. Jääskeläinen IP, Hautamäki M, Näätänen R, Ilmoniemi RJ. Temporal span of human echoic memory and mismatch negativity: revisited. Neuroreport, 1999; 10(6): 1305-8.

145. Pekkonen E, Rinne T, Reinikainen K, Kujala T, Alho K, Näätänen R. Aging effects on auditory processing: an event-related potential study. Exp Aging Res, 1996; 22(2): 171-84. 
146. Cowan N. On short and long auditory stores. Psychol Bull, 1984; 96(2): 341-70.

147. Winkler I, Cowan N. From sensory to long-term memory: evidence from auditory memory reactivation studies. Exp Psychol, 2005; 52(1): 3-20.

148. Winkler I, Kujala T, Alku P, Näätänen R. Language context and phonetic change detection. Cogn Brain Res, 2003; 17(3): $833-44$.

149. Grau C, Polo MD, Yago E, Gual A, Escera C. Auditory sensory memory as indicated by mismatch negativity in chronic alcoholism. Clin Neurophysiol Off J Int Fed Clin Neurophysiol, 2001; 112(5): 728-31.

150. Polo MD, Escera C, Gual A, Grau C. Mismatch negativity and auditory sensory memory in chronic alcoholics. Alcohol Clin Exp Res, 1999; 23(11): 1744-50.

151. Pekkonen E, Jousmäki V, Könönen M, Reinikainen K, Partanen J. Auditory sensory memory impairment in Alzheimer's disease: an event-related potential study. Neuroreport, 1994; 5(18): 2537-40.

152. Pekkonen E. Mismatch negativity in aging and in Alzheimer's and Parkinson's diseases. Audiol Neurootol, 2000; 5(3-4): 216-24.

153. Giard MH, Perrin F, Pernier J, Bouchet P. Brain generators implicated in the processing of auditory stimulus deviance: a topographic event-related potential study. Psychophysiology, 1990; 27(6): 627-40.

154. Schröger E. A neural mechanism for involuntary attention shifts to changes in auditory stimulation. J Cogn Neurosci, 1996; 8(6): 527-39.

155. Alho K, Escera C, Díaz R, Yago E, Serra JM. Effects of involuntary auditory attention on visual task performance and brain activity. Neuroreport, 1997; 8(15): 3233-37.

156. Schröger E. The influence of stimulus intensity and inter-stimulus interval on the detection of pitch and loudness changes. Electroencephalogr Clin Neurophysiol, 1996; 100(6): 517-26.

157. Jankowiak S, Berti S. Behavioral and event-related potential distraction effects with regularly occurring auditory deviants. Psychophysiology, 2007; 44(1): 79-85.

158. Ford JM, Roth WT, Kopell BS. Attention effects on auditory evoked potentials to infrequent events. Biol Psychol, 1976; 4(1): 65-77.

159. Wang J, Friedman D, Ritter W, Bersick M. ERP correlates of involuntary attention capture by prosodic salience in speech. Psychophysiology, 2005; 42(1): 43-55.

160. Ranganath C, Rainer G. Neural mechanisms for detecting and remembering novel events. Nat Rev Neurosci, 2003; 4(3): 193-202.

161. Sokolov EN, Spinks JA, Näätänen R, Lyytinen H. The orienting response in information processing. New York: Lawrence Erlbaum Associates Publishers; 2002.

162. Jääskeläinen IP, Pekkonen E, Hirvonen J, Sillanaukee P, Näätänen R. Mismatch negativity subcomponents and ethyl alcohol. Biol Psychol, 1996; 43(1): 13-25.

163. Dehaene-Lambertz G. Electrophysiological correlates of categorical phoneme perception in adults. Neuroreport, 1997; 8(4): 919-24.

164. Sharma A, Dorman MF. Cortical auditory evoked potential correlates of categorical perception of voice-onset time. J Acoust Soc Am, 1999; 106(2): 1078-83.

165. Szymanski MD, Yund EW, Woods DL. Phonemes, intensity and attention: differential effects on the mismatch negativity (MMN). J Acoust Soc Am, 1999; 106(6): 3492-505.
166. Cheour M, Ceponiene R, Lehtokoski A, Luuk A, Allik J, Alho $\mathrm{K}$ i wsp. Development of language-specific phoneme representations in the infant brain. Nat Neurosci, 1998; 1(5): 351-53.

167. Winkler I, Kujala T, Tiitinen H, Sivonen P, Alku P, Lehtokoski A i wsp. Brain responses reveal the learning of foreign language phonemes. Psychophysiology, 1999; 36(5): 638-42.

168. Näätänen R, Celesia G, Hashimoto I, Kakigi R: Phoneme representations of the human brain as reflected by event-related potentials. W: Hasihimoto I, Kakigi R, Gastone GC, Barber $\mathrm{C}$, red. Functional Neuroscience: Evoked potentials and magnetic fields: the $6^{\text {th }}$ International Evoked Potentials Symposium, Electroencephalography and clinical neurophysiology. Supplement EEG Journal Suppl.; 1999, s. 170-73.

169. Kane NM, Curry SH, Butler SR, Cummins BH. Electrophysiological indicator of awakening from coma. Lancet, 1993; 341(8846): 688.

170. Kane NM, Curry SH, Rowlands CA, Manara AR, Lewis T, Moss T i wsp. Event-related potentials - neurophysiological tools for predicting emergence and early outcome from traumatic coma. Intensive Care Med, 1996; 22(1): 39-46.

171. Sallinen M, Kaartinen J, Lyytinen H. Is the appearance of mismatch negativity during stage 2 sleep related to the elicitation of K-complex? Electroencephalogr Clin Neurophysiol, 1994; 91(2): 140-48.

172. Picton TW, Alain C, Otten L, Ritter W, Achim A. Mismatch negativity: different water in the same river. Audiol Neurootol, 2000; 5(3-4): 111-39.

173. Leppänen PH, Lyytinen H. Auditory event-related potentials in the study of developmental language-related disorders. Audiol Neurootol, 1997; 2(5): 308-40.

174. Csépe V, Molnár M. Towards the possible clinical application of the mismatch negativity component of event-related potentials. Audiol Neurootol, 1997; 2(5): 354-69.

175. Kraus N, McGee TJ. Mismatch negativity in the assessment of central auditory function. Am J Audiol, 1994; 3(2): 39-51.

176. Oates PA, Kurtzberg D, Stapells DR. Effects of sensorineural hearing loss on cortical event-related potential and behavioral measures of speech-sound processing. Ear Hear, 2002; 23(5): 399-415.

177. Azizian A, Freitas AL, Parvaz MA, Squires NK. Beware misleading cues: perceptual similarity modulates the N2/P 3 complex. Psychophysiology, 2006; 43(3): 253-60.

178. Gajewski PD, Stoerig P, Falkenstein M. ERP—Correlates of response selection in a response conflict paradigm. Brain Res, 2008; 1189: 127-34.

179. Koravand A, Jutras B, Lassonde M. Cortical Auditory Evoked Potentials in Children with a Hearing Loss: A Pilot Study. Int J Pediatr, 2012; 2012: e250254.

180. Folstein JR, Petten C Van. Influence of cognitive control and mismatch on the N2 component of the ERP: A review. Psychophysiology, 2008; 45(1): 152-70.

181. Papaliagkas V, Kimiskidis V, Tsolaki M, Anogianakis G. Usefulness of event-related potentials in the assessment of mild cognitive impairment. BMC Neurosci, 2008; 9: 107.

182. Miyata A, Matsunaga H, Kiriike N, Iwasaki Y, Takei Y, Yamagami S. Event-related potentials in patients with obsessive-compulsive disorder. Psychiatry Clin Neurosci, 1998; 52(5): $513-18$.

183. Urretavizcaya M, Moreno I, Benlloch L, Cardoner N, Serrallonga J, Menchón JM i wsp. Auditory event-related potentials in 50 melancholic patients: increased N100, N200 and P300 latencies and diminished P300 amplitude. J Affect Disord, 2003; 74(3): 293-97. 
184.Zgorzalewicz M. [Long latency auditory evoked potentials in schoolchildren and adolescents with epilepsy]. Przegląd Lek, 2006; 63 Suppl 1: 8-13.

185. Wang R, Dong Z, Chen X, Zhang M, Yang F, Zhang X i wsp. Gender differences of cognitive function in migraine patients: evidence from event-related potentials using the oddball paradigm. J Headache Pain, 2014; 15: 6.

186. Fisher T, Aharon-Peretz J, Pratt H. Dis-regulation of response inhibition in adult Attention Deficit Hyperactivity Disorder (ADHD): an ERP study. Clin Neurophysiol Off J Int Fed Clin Neurophysiol, 2011; 122(12): 2390-99.

187. Fischer M, Barkley RA, Smallish L, Fletcher K. Executive functioning in hyperactive children as young adults: attention, inhibition, response perseveration, and the impact of comorbidity. Dev Neuropsychol, 2005; 27(1): 107-33.

188. Lijffijt M, Kenemans JL, Verbaten MN, Engeland H van. A meta-analytic review of stopping performance in attention-deficit/hyperactivity disorder: deficient inhibitory motor control? J Abnorm Psychol, 2005; 114(2): 216-22.

189. Kaufmann L, Zieren N, Zotter S, Karall D, Scholl-Bürgi S, Haberlandt E i wsp. Predictive validity of attentional functions in differentiating children with and without ADHD: a componential analysis. Dev Med Child Neurol, 2010; 52(4): 371-8.

190. Metin B, Roeyers H, Wiersema JR, Meere J van der, Sonuga-Barke E. A Meta-Analytic Study of Event Rate Effects on Go/ No-Go Performance in Attention-Deficit/Hyperactivity Disorder. Biol Psychiatry, 2012; 72(12): 990-96.

191. Nigg JT. Is ADHD a disinhibitory disorder? Psychol Bull, 2001; 127(5): 571-98.

192. Bezdjian S, Baker LA, Lozano DI, Raine A. Assessing inattention and impulsivity in children during the Go/NoGo task. Br J Dev Psychol, 2009; 27(2): 365-83.

193. Tye C, Asherson P, Ashwood KL, Azadi B, Bolton P, McLoughlin G. Attention and inhibition in children with ASD, ADHD and co-morbid ASD + ADHD: an event-related potential study. Psychol Med, 2014; 44(5): 1101-16.

194. Chermak GD, Tucker E, Seikel JA. Behavioral characteristics of auditory processing disorder and attention-deficit hyperactivity disorder: predominantly inattentive type. J Am Acad Audiol, 2002; 13(6): 332-8.

195. Sparreboom M, Beynon AJ, Snik AFM, Mylanus EAM. Auditory cortical maturation in children with sequential bilateral cochlear implants. Otol Neurotol Off Publ Am Otol Soc Am Neurotol Soc Eur Acad Otol Neurotol, 2014; 35(1): 35-42.

196. Schmitt BM, Münte TF, Kutas M. Electrophysiological estimates of the time course of semantic and phonological encoding during implicit picture naming. Psychophysiology, 2000; 37(4): 473-84.

197. Polich J, Ehlers CL, Otis S, Mandell AJ, Bloom FE. P300 latency reflects the degree of cognitive decline in dementing illness. Electroencephalogr Clin Neurophysiol, 1986; 63(2): 138-44.

198. Polich J, Corey-Bloom J. Alzheimer's disease and P300: review and evaluation of task and modality. Curr Alzheimer Res, 2005; 2(5): 515-25.

199. Matas CG, Matas SL de A, Oliveira CRS de, Gonçalves IC. Auditory evoked potentials and multiple sclerosis. Arq Neuropsiquiatr, 2010; 68(4): 528-34.
200. Matas CG, Gonçalves IC, Magliaro FCL. Audiologic and electrophysiologic evaluation in children with psychiatric disorders. Braz J Otorhinolaryngol, 2009; 75(1): 130-38.

201. Müller TJ, Kalus P, Strik WK. The neurophysiological meaning of auditory P300 in subtypes of schizophrenia. World J Biol Psychiatry Off J World Fed Soc Biol Psychiatry, 2001; 2(1): 9-17.

202. Salamat MT, McPherson DL. Interactions among variables in the P300 response to a continuous performance task. J Am Acad Audiol, 1999; 10(7): 379-87.

203. Hurley RM, Musiek FE. Effectiveness of three central auditory processing (CAP) tests in identifying cerebral lesions. J Am Acad Audiol, 1997; 8: 257-62.

204. Hutchinson KM, McGill DJ. The efficacy of utilizing the P300 as a measure of auditory deprivation in monaurally aided profoundly hearing-impaired children. Scand Audiol, 1997; 26(3): 177-85.

205. Kileny PR. Use of electrophysiologic measures in the management of children with cochlear implants: brainstem, middle latency, and cognitive (P300) responses. Am J Otol, 1991; 12 Suppl: $37-42 ; 43-47$.

206. Jordan K, Schmidt A, Plotz K, Specht H Von, Begall K, Roth $\mathrm{N}$ i wsp. Auditory event-related potentials in post-and prelingually deaf cochlear implant recipients. Am J Otol, 1997; 18(6 Suppl): 116-17.

207. Micco AG, Kraus N, Koch DB, McGee TJ, Carrell TD, Sharma A i wsp. Speech-evoked cognitive P300 potentials in cochlear implant recipients. Otol Neurotol, 1995; 16(4): 514-20.

208. Moore DR, Ferguson MA, Edmondson-Jones AM, Ratib S, Riley A. Nature of auditory processing disorder in children. Pediatrics, 2010; 126(2): e382-90.

209. Moore DR. The diagnosis and management of auditory processing disorder. Lang Speech Hear Serv Sch, 2011; 42(3): 303.

210. Moore DR. Listening difficulties in children: Bottom-up and top-down contributions. J Commun Disord, 2012.

211. Jirsa RE. The clinical utility of the P3 AERP in children with auditory processing disorders. J Speech Hear Res, 1992; 35(4): 903-12.

212. Byrne JM, Dywan CA, Connolly JF. An innovative method to assess the receptive vocabulary of children with cerebral palsy using event-related brain potentials. J Clin Exp Neuropsychol, 1995; 17(1): 9-19.

213. Byrne JM, Connolly JF, MacLean SE, Dooley JM, Gordon KE, Beattie TL. Brain activity and language assessment using event-related potentials: Development of a clinical protocol. Dev Med Child Neurol, 1999; 41(11): 740-47.

214. Arcy RCN D', Marchand Y, Eskes GA, Harrison ER, Phillips SJ, Major A i wsp. Electrophysiological assessment of language function following stroke. Clin Neurophysiol Off J Int Fed Clin Neurophysiol, 2003; 114(4): 662-72.

215. Kojima T, Kaga K. Auditory lexical-semantic processing impairments in aphasic patients reflected in event-related potentials (N400). Auris Nasus Larynx, 2003; 30(4): 369-78.

216. Kutas M, Hillyard SA. Event-related brain potentials to grammatical errors and semantic anomalies. Mem Cognit, 1983; 11(5): 539-50. 